\title{
SARMATIAN BURIALS WITH ROMAN IMPORTS FROM WALLACHIA
}

\author{
L I A N A O Ț A
}

\begin{abstract}
Starting with the end of the $1^{\text {st }} \mathrm{c}$. AD, the arrival of the Sarmatian communities in Wallachia (the area between the Danube River and the Carpathian Mountains, bounded on the west by the Olt River) and Moldavia (denomination that designates in this study the territory between the Prut River and the Carpathian Mountains) is archaeologically attested. Sarmatian graves in Wallachia are dated to three stages, which represent as many moments of settlement of these communities in Wallachia: the late $1^{\text {st }} \mathrm{c}$. AD and the first half of the $2^{\text {nd }} \mathrm{c}$. AD; the late $2^{\text {nd }} \mathrm{c}$. and the first half of the $3^{\text {rd }} \mathrm{c}$. AD; the late $3^{\text {rd }}$ c. AD. From a total of around 270 Sarmatian graves in Wallachia, Roman imports were discovered in 71 of them. The purpose of this discussion is not so much the typological analysis of the Roman items, but rather the characteristics of the ritual and funerary inventory of the graves in which such items were deposited: territorial distribution, grave layout, corpse deposition, age and sex of the deceased, grave goods. Based on the typology of the Roman objects, the hypothesis of trade is the most appropriate explanation for the way the Roman products reached Sarmatian communities from Wallachia. The conclusion is that the Sarmatian burials with Roman grave goods do not have particular features regarding the layout of the grave, the funerary ritual or the treatment of the inventory deposited compared to the rest of the graves in which no items produced on the Roman territory were found. Although, in some cases, the items from the Roman Empire can be counted among the status symbols used in the funerary ritual, it is nevertheless notable that they do not play this role in themselves, but in association with other features of the layout of the graves or the inventory.
\end{abstract}

Keywords: Sarmatians, Roman Empire, Wallachia, burials, grave goods, Roman products, $1^{\text {st }}-3^{\text {rd }}$ c. AD.

The study of the Roman objects found in Barbaricum is an important research direction, essential for understanding the relations between the Roman Empire and different populations located either closer or farther from its borders. Several monographs have already been written about the North-Pontic area, summarizing the Roman discoveries in the region (Simonenko 2011; 2013; Simonenko/ Marčenko/Limberis 2008). At first sight, the usefulness of the following approach could be questioned judging from the point of view of the monographs mentioned above and considering that we are talking about the same population - the Sarmatians, and a geographically close area. However, a close look at the Sarmatian discoveries in Wallachia indicates a different situation.

Starting with the end of the $1^{\text {st }} \mathrm{c}$. AD, the arrival of the Sarmatian communities in Wallachia (the area between the Danube River and the Carpathian mountains, bounded on the west by the Olt River) and Moldavia (denomination that designates in this study the territory between the Prut River and the Carpathian mountains) is archaeologically attested (Oța 2016, 129-138; Oța/Sîrbu 2010, 191-201; 2016a, 261-284; 2016b, 212-214, 228-230; 2019a, 151-154). The discoveries are not very numerous (around 220 in the territory west of the Prut River and around 270 in the area between the Danube and the Carpathians), especially if we consider that they extend chronologically over a period of about two centuries and they are not evenly distributed territorially. The Sarmatian discoveries in Wallachia are concentrated mainly in the east, north-east and south of the region, less in the central and northern areas and appear only sporadically west of the limes transalutanus. In Moldavia, the discoveries attributed to the Sarmatians are grouped in the Jijia Plain, the Bârlad Plateau, the Tutova Hills and the Siret Plain (Oța/Sîrbu 2016a, 262-265; 2016b, 212-214, 228-230; 2019a, 151-154). Both Wallachia and Moldavia represent marginal areas compared to the vast space (Istvánovits/Kulcsár 2017, 1-14) inhabited by the populations generically designated by the ancient written sources as 'Sarmatians' (Olbrycht 2000, 116-129; for doubts regarding the use of this term, see Dan 2017, 113; Mordvintseva 2013, 203-216; for the denominations Germania and Sarmatia as Roman constructions see Lind 1991, 133, 138).

The study of the Roman products is of particular importance in understanding the Sarmatian discoveries in Wallachia and Moldavia. These discoveries consist almost exclusively of graves, with very few exceptions represented by accidental discoveries or discoveries from systematic excavations which however had other objectives (Sîrbu et al. 2014, 94). The inventory of the graves is modest, consisting mainly of handmade or wheel-made pottery, adornment items (especially beads), less frequently weapons or mirrors (Bichir 1972, 145-166; 1977, 174-188; Oțal Sirbu 2009, 145-177; Sîrbu et al. 2014, 101-118). The 
dating of the inventory items is difficult, because their typology does not vary much over time, and this is also why the chronology of the Sarmatian discoveries in Wallachia and Moldavia has remained, for a long time, a very general one $\left(2^{\text {nd }}-3^{\text {rd }} c\right.$. AD; Bichir 1971, 280, 281; 1972, 166-169; 1977, 191-193). The resumption of the study of the Roman imports found in Wallachia finally meant the opportunity to elaborate a more detailed chronology of some of the discoveries which were treated for a long time en bloc and to distinguish among them three chronological stages corresponding to the different times when the Sarmatian communities arrived in Wallachia: the end of the $1^{\text {st }} \mathrm{c}$. AD-the first decades of the $2^{\text {nd }} \mathrm{c}$. $\mathrm{AD}$; the end of the $2^{\text {nd }} \mathrm{c}$. and the first decades of the next century; the end of the $3^{\text {rd }} \mathrm{c}$. AD (Oța 2016, 131-146; Oța/Sîrbu 2009, 178-183; 2013, 292, 293; 2016b, 212, 213, 228, 229; 2019a, 151-157; Sîrbu et al. 2014, 121-133).

Although geographically close and inhabited by the same populations, the regions between the Carpathians and the Danube (Wallachia) and between the Carpathians and the Prut (Moldavia) must be approached differently at least in terms of the Sarmatian discoveries (Oța/Sîrbu 2016b, 215-220, 230-235), and this is why this study focuses only on the Roman objects from the Sarmatian graves or the very few random discoveries in Wallachia. Behind certain common features are hidden many differences of detail, important for understanding the general or particular characteristics revealed by the discoveries in a certain region, and the case of the Sarmatians is a typical one. The indication of the great variety of populations that hid under the generic name of Sarmatians (name given on the basis of certain general features common to these populations) is due first and foremost to the ancient authors, and the term of 'Sarmatians' will be used with the same meaning in this paper: a generic term covering a diversity of tribes, which most likely had specific names, but which shared several common features (Oța 2018, 41; Oța/Sîrbu 2012, 128).

The Roman objects found in Sarmatian cultural milieu from Wallachia were published in detail in two monographs (Oța/Sîrbu 2009, 13-72; Sîrbu et al. 2014, 15-91), and based on them several studies were written on the features of the Sarmatian graves in the mentioned region (Oța 2014-2015, 95-118; 2016, 129-146; 2018, 41-61; Oța/Sîrbu 2012, 125-148; 2016a, 261-280; 2016b, 205-235; 2019a, 149-157; Oța/Sîrbul Matei 2013, 325-352). However, a synthesis study on the items produced in the Roman Empire found in the Sarmatian graves in Wallachia represents a useful approach. ${ }^{1}$ Not only does this study gather data published so far in a disparate manner, but it also orders and completes them in an approach dedicated especially to the Roman products, following which the image of the relations between the Roman Empire and the Sarmatian communities around the Danubian limes will become better known.

From the outset, attention should be drawn to a limitation. ${ }^{2}$ In overwhelming proportion, the Sarmatian discoveries in Wallachia consist so far of graves and, because of a few reasons, the items deposited as funerary inventory provide only an incomplete sequence. The first of these reasons is that we are dealing with only certain items belonging to the deceased or his family, which were intentionally selected by those who performed the funerary ritual (most likely relatives) in order to be removed from the everyday use (Forest 1998, 247) and buried in the grave. Most likely, the items deposited as funerary inventory do not cover the whole variety of objects used in the daily life (Brather 2008, 239; Roymans 2007, 479; Tuffreau-Libre 2000, 54), therefore the conclusions derived from the study of the funerary inventory can only be used with caution as a basis for certain assumptions about the way of life, the social organization or even the religious beliefs of the various populations. A second reason is related to the proportion in which a grave mirrors the social status, aspirations or achievements of the buried individual. In some cases, rather than a true reflection of the reality, one can speak of a real transformation (Härke 1994, 31-34; Pearce 2000, 5, 8) of the said reality, a reason for a family or for the person who performs the funerals, especially in the case of a usurpation, to display their status and to try to legitimize certain claims, by manipulating public opinion (Mordvintseva 2016, 390, 391). The third reason is represented by the inherent lack of uniformity of the funerary ritual. Even in the Roman world, for which there are numerous literary or epigraphic sources, there is no uniform funerary

\footnotetext{
1 The study I have published several years ago (Oța 2015a,25-33) was a very general one, focusing only on some characteristics of the Roman imports, mainly from north-eastern and southern Wallachia. The studies of A. Popa $(2011 ; 2013)$ on the Roman imports in the area between the Carpathians and the Dniester are also general, as geographical area and the issues discussed. In the synthesis written by the same author, the discussion about the Sarmatians is a general one, focusing especially on the relation between what was defined as 'Sarmatian' culture and the Sarmatians as historically attested people (Popa 2015, 43-46). Some of the Roman grave goods from Sarmatian burials in Wallachia are mentioned in the chapter dedicated to archaeological discoveries from the area between the Eastern Carpathians, Dniester and Lower Danube, but the discussion focuses especially on the typology of the items, not on the role they played in the graves.

2 For a more detailed discussion, see Oța/Sîrbu 2019b, in press.
} 


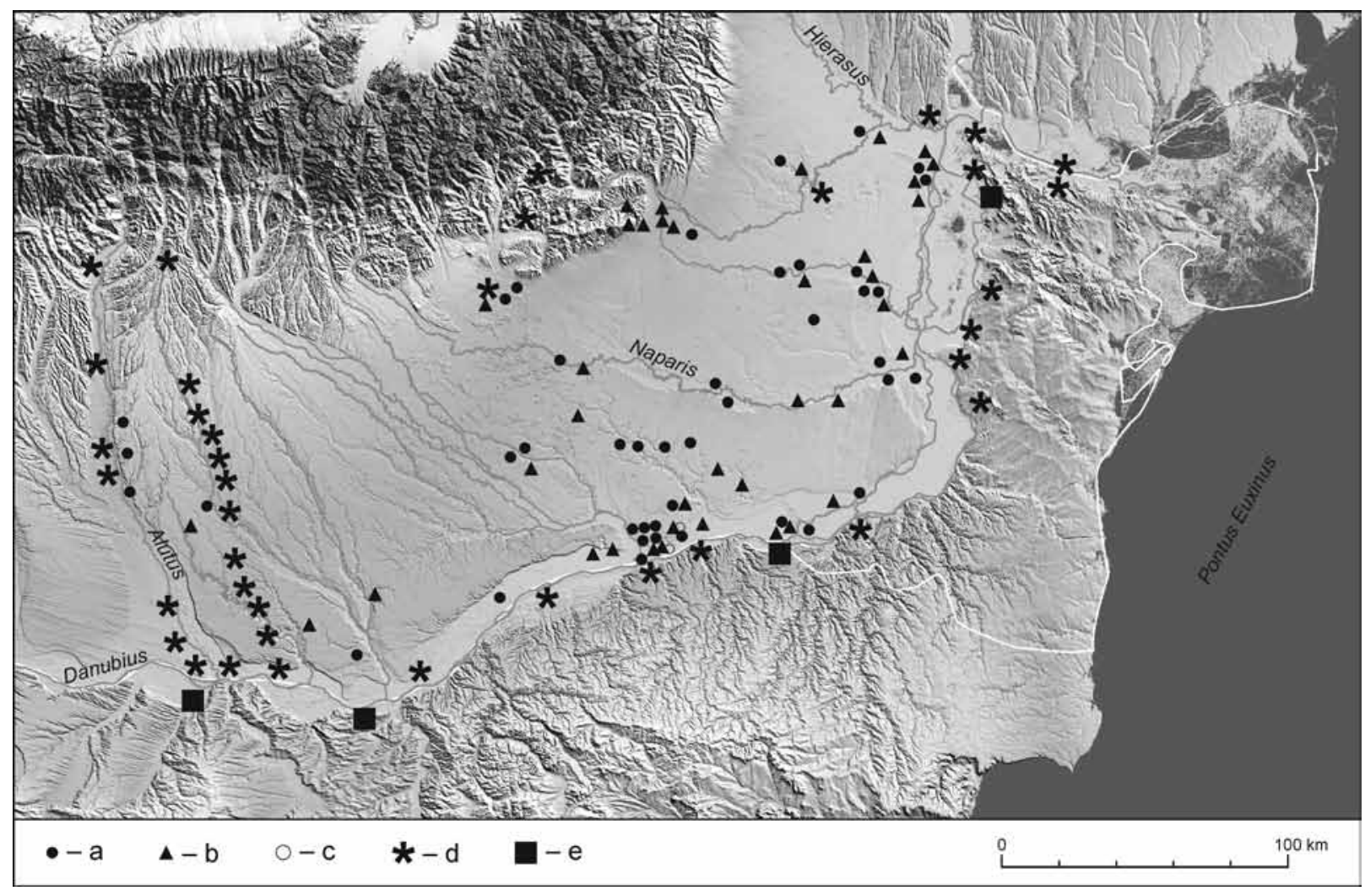

Fig. 1. Roman objects in Sarmatian milieu from Wallachia. Legend: a - Sarmatian graves; b - Sarmatian graves with Roman objects; c - Roman objects with unknown context; d - Roman fortifications; e - legionary forts (map support provided by Mihai Florea, SRTM-30; mapping by Liana Oța).

ritual for all its inhabitants, immutable over time. Common to each family is only the obligation to bury their dead. Otherwise, the way they did it was at their discretion, emphasizes J. Scheid $(2008,7)$. The variety of the funerary rituals must be even greater in the case of a population that has never developed a state (Kradin 2000, 426-431; 2002, 371, 372, 375; 2014, 14-17; Rogers 2007, 250, 251, 257) capable of imposing certain general rules valid for all its subjects. Moreover, written accounts about the Sarmatian funerals are missing, which accounts could have allowed a comparison between what was left of a ritual (the grave is only the often incomplete result of a ceremonial that could in fact have lasted several days and could have involved a succession of acts, gestures and behaviors, and from which the funerary structure could only render quite little information - Février 1987, 81; Parker-Pearson 1999, 1-3) and the written record, even partial, of certain funerals.

Given that the Sarmatian communities from Wallachia are so far archaeologically known to us only through the graves (not much data can be deduced from the few discoveries which do not represent burials, since most are accidental discoveries, without a clear archeological context), we can only try to use this data with all the caution dictated by their incomplete and subjective nature.

From a total of around 270 Sarmatian graves in Wallachia (Fig. 1), Roman imports were discovered in 71 of them (representing 26.29\%). By Roman import $^{3}$ I understood any item manufactured in a province of the Roman Empire, which arrived in the Sarmatian environment from Wallachia, within the chronological frame of the early Roman age, more precisely $1^{\text {st }}-3^{\text {rd }}$ centuries $\mathrm{AD}(\mathrm{Ottal}$ Sîrbu 2009, 168, 169; see also Krekovič 1987, 275 for the definition of Roman imports in Slovakia and Lund-Hansen 1987, 13 for northern Europe). Most of these products arrived in Barbaricum by trade, but in certain particular cases other means, such as robbery, diplomatic gift, subsidies, payment of mercenaries, even souvenirs, should be taken into account, at least for other areas (Laser/von Schnurbein 1994, 2; Meyer 2013, 58, 70, 71; Popa 2015, 184-188; Vaday 2005, 10-13).

Although I tried to make the distinction when possible, it is not completely excluded that some of

\footnotetext{
3 A.Vaday $(2005,17)$ believes it would be more appropriate to talk about Roman 'exports' than about Roman imports.
} 
the analyzed items were not products of the Roman workshops, but of the North-Pontic ones. Given the fact that starting with the seventh decade of the $1^{\text {st }} \mathrm{c}$. $\mathrm{AD}$ the Roman domination expanded also over the north of the Black Sea (Ferrary 2007, 324; Petolescu 2000, 48), the inclusion of such products among the Roman imports in the broad sense explained above, is not, however, a mistake. What I excluded are the items of North-Pontic origin that were, most likely, brought by the Sarmatians to Wallachia from their areas of origin. A legitimate question would be how we can make such a distinction between the items brought by the Sarmatians from the North-Pontic areas and the Roman products acquired after their arrival in Wallachia. I have supposed that items of North-Pontic origin found in some early Sarmatian graves most probably were brought in Wallachia by the Sarmatians as part of their traditional attire. These items are not testimonies of establishing certain relations of the Sarmatian communities with the Roman Empire in the new area in which they made their presence archaeologically felt, but they must be related to the costume and fashion in the areas of origin (Vaday 2005, 15). The discontinuance in the supply of products from the area of origin and their replacement with Roman products had as a consequence the change in a relatively short time (visible changes sometimes starting even with the second generation), of the originary costume attested in the new areas where Sarmatians settled (Vaday/Istvánovits/Kulcsár 1989, 111).

However, it should be noted from the beginning that not all the Sarmatian funerary structures in Wallachia have been published. Out of the 36 graves attributed to the Sarmatians at Târgșor (Ciupercă) Măgureanu/Anton 2015, 777) only 18 were published (Diaconu 1963, 324-336; 1965, 19-29), while for the remaining 18 there are only mentions, among which the existence of three Roman vessels deposited as funerary inventory (Niculescu 2003, 193-195). The presence of beads and pendants (Sîrbu et al. 2014, 37, 38 , nos. 11, 12) in the inventory of one of the Sarmatian graves at Chirnogi-Terasa Rudarilor (group of eight burials) or Chirnogi-Șuvița Iorgulescu (one structure; Situri 1983-1992, 33) could be an indication of the presence of other unpublished Roman items. However, given the fact that the aforementioned Sarmatian graves were discovered earlier (Chirnogi in 1988 and 1989, and Târgșor before 2003) and are still unpublished, we can attempt to make a synthesis with the existing data. Given that the material already published preponderates over the unpublished one, it is difficult to believe that the observations and conclusions will change radically.

I have excluded the three Roman vessels from Târgșor from the present synthesis, because I do not know if they represent as many different graves or if some of them were associated in the inventory of the same grave. However, I took into account the typology of the three vessels (mug, bowl and handled pot) and, where possible, more precisely when discussing the typology and chronology of the Roman objects, I also made references to these findings. On the other hand, even if no additional data was published about the inventory of the grave at Chirnogi besides the existence of beads and pendants, given that the respective items are illustrated, I have introduced the mentioned funerary structure in the analysis undertaken, with all due reservations. I have also excluded from among the published graves G. 205 at Târgșor (Diaconu 1963, $325,330,334 ; 1965,21,25,28)$, in which the only item likely to be classified among the Roman objects, the amber bead, was in fact discovered in a robbery pit, which raises questions about its belonging to the grave goods. G. 3 from Smeeni-Movila Mare (Bichir 1972, 156; 1977, 184; Frînculeasa et al. 2017, 55; Simache/Teodorescu 1962, 270-280) was also not discussed, because the reference in the initial publication of a bell in the inventory of the grave is under question and there are still reservations even after the monographic publication, as the item could not be found.

The purpose of this discussion is not so much the typological analysis of the Roman items (since many of them have already been published, with the corresponding analogies - Oța/Sîrbu 2009, 13-72; Sîrbu et al. 2014, 15-91), but rather the characteristics of the ritual and funerary inventory of the graves in which such items were deposited. The reason for this choice is that, in the absence of settlements, the discussion on the Sarmatian communities in Wallachia should be carried out on the basis of the available information, which consists almost exclusively of funerary findings, therefore it must be verified which is the place occupied by these burials in which Roman items were deposited as part of the Sarmatian funerary customs, more precisely if they are characterized by other particular features than by the deposit of Roman products. Equally significant is the treatment of the Roman items in relation to the rest of the funerary inventory.

Only a small number of Roman objects represents stray finds: the mugs from Oltenița-Renie and Ulmeni, the ring from Oltenița-Renie, the bronze casserole and the glass unguentarium from Ulmeni. Unfortunately, it is impossible to know for sure whether all these finds or a part of them belonged to graves destroyed by modern irrigation works (Bichir 1972, 166; 1977, 191, although the authors who published for the first time the three vessels from Ulmeni - Morintz/Ionescu 1968, 109 - avoided 
Table 1. The percentage of graves with Roman products in the groups of Sarmatian graves.

\begin{tabular}{|c|c|c|c|c|}
\hline No. & Group of graves & $\begin{array}{l}\text { Number of graves } \\
\text { with Roman products }\end{array}$ & Total number of graves & $\begin{array}{l}\text { Percentage of graves } \\
\text { with Roman products }\end{array}$ \\
\hline 1. & Ulmeni & 5 & 5 & $100.00 \%$ \\
\hline 2. & Largu & 7 & 10 & $70.00 \%$ \\
\hline 3. & Gălățui & 2 & 3 & $66.60 \%$ \\
\hline 4. & Lișcoteanca-Moș Filon & 3 & 6 & $50.00 \%$ \\
\hline 5. & Tichilești & 2 & 4 & $50.00 \%$ \\
\hline 6. & Vlad Țepeș & 1 & 2 & $50.00 \%$ \\
\hline 7. & Oltenița-Puțul de cărămidă & 1 & 2 & $50.00 \%$ \\
\hline 8. & Brăila-Hipodrom & 2 & 5 & $40.00 \%$ \\
\hline 9. & Târgșor & 7 & 18 published & $38.88 \%$ \\
\hline 10. & Jilava & 1 & 3 & $33.30 \%$ \\
\hline 11. & Smeeni-Movila Mare & 1 & 3 & $33.30 \%$ \\
\hline 12. & Ciulnița & 2 & 6 & $33.30 \%$ \\
\hline 13. & Spiru Haret & 1 & 3 & $33.30 \%$ \\
\hline 14. & Buzău-sud & 2 & minimum 7 & $28.57 \%$ \\
\hline 15. & Bucu & 4 & 14 & $28.57 \%$ \\
\hline 16. & Râmnicelu & 4 & 16 & $25.00 \%$ \\
\hline 17. & Grădiștea & 2 & 10 & $20.00 \%$ \\
\hline 18. & Călărași G. 7-10 & 1 & 5 & $20.00 \%$ \\
\hline 19. & Dorobanțu & 1 & 5 & $20.00 \%$ \\
\hline 20. & Oltenița-Renie & 3 & 16 & $18.75 \%$ \\
\hline 21. & Lișcoteanca-Movila Olarului & 2 & 12 & $16.66 \%$ \\
\hline 22. & Păuleasca & 1 & 6 & $16.66 \%$ \\
\hline
\end{tabular}

making any assumption), and so, the data on these discoveries can only be useful when discussing the typology of the Roman items found in Wallachia.

\section{THE FUNERARY RITE AND RITUAL OF THE SARMATIAN GRAVES FROM WALLACHIA CONTAINING ROMAN GRAVE GOODS}

It is not known whether G. 2 from Călărași ${ }^{4}$ and the funerary structure from Chirnogi represent isolated burials or they belong to a group of graves. 14 of the 69 remaining graves represent isolated burials and 55 graves were found in 22 groups of graves, while their proportion within the group (Table 1) vary between a presence of $100 \%$ (Ulmeni) and 16.66\% (Păuleasca and LișcoteancaMovila Olarului). In nine groups, the percentage of the graves with Roman products ranges between $16.66 \%$ and $30 \%$ (Păuleasca and Lișcoteanca-Movila Olarului with $16.66 \%$, Oltenița-Renie with $18.75 \%$, Grădiștea, Călărași G. 7-10 and Dorobanțu with $20 \%$, Râmnicelu with 25\%, Bucu and Buzău-sud with $28.57 \%$ ). In six groups there are percentages between 30 and 40\% (Jilava, Smeeni-Movila Mare, Spiru Haret and Ciulnița with 33.3\%, Târgșor with - so far $-38.88 \%$, Brăila-Hipodrom with $40 \%$ ) and only in seven groups were found percentages between 50 and $100 \%$, as follows: $50 \%$ in four cases (Lișcoteanca-Moș Filon, Tichilești, Vlad Țepeș and Oltenița-Puțul de cărămidă), $66.6 \%$ in one case (Gălățui), 70\% in one case (Largu) and 100\% also in one case (Ulmeni). The groups of Sarmatian graves in Wallachia have varied numbers, between a minimum of two and a maximum of 16 burials, however it is worth noting the tendency that - in the case of large groups (with more than $10 \mathrm{bu}-$ rials) - the number of funerary structures in which Roman items were deposited is rather low $(16.66 \%$ in Lișcoteanca-Movila Olarului, $18.75 \%$ in OltenițaRenie, 20\% in Grădiștea, 25\% in Râmnicelu, 28.57\% in Bucu, $38.88 \%$ in Târgșor), with the two exceptions which are Largu (70\%) and Ulmeni (100\%). A first observation that emerges from the comparison of these percentages is that of a low overall presence of the Roman items deposited as grave goods, regardless of whether all the Sarmatian burials in Wallachia or only the graves of a single group are taken into account. It cannot be known whether this

\footnotetext{
4 For the bibliographical references on each grave, see the catalogue, at the end of this study.
} 
low percentage of Roman objects is only a feature of the funerary inventory or it reflects the same situation in the case of the settlements. Therefore, no hypothesis can be advanced at the moment as to the cause of this low presence of Roman items in the graves (either consequence of a low inflow of Roman products in the Sarmatian communities in Wallachia, or symbol of a high value of these items, which is why they are not removed from the daily life).

Regardless of whether they are isolated or part of groups, most of the graves with Roman objects are flat (43), 14 are burials arranged in tells (from the groups found at Lișcoteanca-Moș Filon, LișcoteancaMovila Olarului, Râmnicelu, Spiru Haret, Gălățui, Dridu-tell, Sudiți), and seven graves (all from the same group - Largu) were discovered in sand dunes. The number of tumular burials is low - only six, of which five are secondary (Mohreanu, Jilava G. 2, Ciulnița G. 1 and G. 4, Smeeni-Movila Mare G. 2) and a main one (Vitănești). There is no such data about the funerary structure at Chirnogi.

Usually, only one deceased was put in a grave, with the exception of G. 1 in Ciulnița, where two deceased, male and female, were buried together. ${ }^{5}$

Unfortunately, the orientation of the deceased individuals is not known for 15 burials, either because it could no longer be determined due to the destruction of the grave, or because it was not published. For the remaining 56 graves, the orientation predominates in the $\mathrm{N}-\mathrm{S}$ direction (44 burials), while orientations such as NW - SE (four cases: Brăila-Liceu, Bucu G. 14, Grădiștea G. 19, Lișcoteanca-Moș Filon G. 3), NE - SW (one grave: Ciulnița G. 4), E - W (four cases: Brăila-Hipodrom G. 2, G. 3, Râmnicelu G. 9. Smeeni-Movila Mare G. 2) or W-E (three burials: Lișcoteanca-Moș Filon G. 6, Râmnicelu G. 5, Ulmeni G. 5) are sporadic. The explanation is related to the general tendency observed in the areas of Wallachia where the Sarmatian discoveries were concentrated. The orientation on the $\mathrm{N}-\mathrm{S}$ direction is predominant both in the Sarmatian funerals in Wallachia as a whole, as well as in the various regions. The weight of the exceptions (orientations on the $\mathrm{E}-\mathrm{W}, \mathrm{W}-\mathrm{E}$ or $\mathrm{S}-\mathrm{N}$ directions) is overall small, but attention should be drawn to the higher frequency of these exceptions in the case of the graves found in the north-east and east of Wallachia, more precisely Brăila Plain (Oța/Sîrbu 2009, 140, 141) and Buzău area, compared to the south of Wallachia. The seven graves with Roman items oriented $\mathrm{E}-\mathrm{W}$ or $\mathrm{W}-\mathrm{E}$ are found exclusively in the east and north-east of Wallachia, with the sole exception of G. 5 from Ulmeni, found in the south of Wallachia.

In the two monographs published so far about the Sarmatian discoveries in the Brăila Plain and in southern Wallachia we have tried to number the positions of the deceased individuals in order to see if there are certain rules regarding the deposition of the deceased (Oța/Sirbu 2009, 141-143; Sîrbu et al. 2014, 96-98). Drawing attention to the unexpectedly large number in which the position of the deceased individuals was not known, especially in southern Wallachia (72 graves out of a total of 121, compared to only 42 burials for which the positions of the deceased individuals are known - Sirbu et al. 2014, 96, 97), the conclusion was that of the predominance of the body laid out in dorsal position, with arms and legs straight. The aforementioned position also predominates in the graves with Roman objects ( 35 burials). With the exception of the body laid out in dorsal position, with the palms on the pelvis, discovered in three graves with Roman items (Lișcoteanca-Moș Filon G. 6, Lișcoteanca-Movila Olarului G. 7, Dridutell G. 2), in the case of the other 11 graves we can only speak of positions recorded just once: dorsal position, with palms on the chest (Lișcoteanca-Moș Filon G. 3); dorsal position, with the right arm bent from the elbow and oriented to the skull (Râmnicelu G. 9); dorsal position, with the right palm on the femur and left arm stretched, with the palm under the pelvis (Lișcoteanca-Moș Filon G. 1); lying on the back, with both arms along the body and legs bent from the knee and fallen to the right, which might suggest an initial lying down with the legs bent and the knees up (Târgșor G. 200); dorsal position, with left leg bent, right one stretched and both arms straight (Grădiștea G. 11); supine position, with right leg bent, the left one stretched, both arms straight (Tichilești G. 2); lying on the back, with arms straight, left femur put across the right one (Gălățui G. 3); dorsal position, left arm stretched and the right arm bent, with the palm to the head (Măriuța G. 2/2009); lying on the right side, with arms and legs stretched (Râmnicelu G. 3); lying on the right side, with the right arm stretched, left one bent, with palm on the pelvis and the legs bent from the knee and fallen to the right (Păuleasca G. 57); lying on the left side, with both legs bent from the knees, forming a rhomb, left arm straight, right arm bent, palm laterally placed, at some distance from the body (Mohreanu). Unfortunately, the observation of the large number of cases in which the data on the burial position of the individuals is absent remains valid also in the case of the graves with Roman items (22 graves).

\footnotetext{
5 Only the woman buried in the double grave from Ciulnița has Roman objects as grave goods, and this is the reason why I have considered, for the present discussion, this double grave as a single case.
} 
Leaving aside the 23 burials for which the age of the deceased individuals is unknown or could not be determined ${ }^{6}$, the Roman items were rather deposited in graves of adults (32 graves: Gălățui G. 3, Lișcoteanca-Moș Filon G. 1, G. 6, LișcoteancaMovila Olarului G. 7, Măriuța G. 2/2009, Mohreanu, Oltenița-Renie G. 9, Păuleasca G. 57, Tichilești G. 2, G. 4, Brăila-Hipodrom G. 2, G. 3, Brăila-Liceu, Bucu G. 8, G. 10, G. 14, Chiscani-sat, Târgșor G. 184, G. 198, G. 200, G. 206, G. 228, G. 253, G. 267, Vitănești G. 2, Smeeni-Movila Mare G. 2, Largu G. 5, G. 6, G. 7, G. 8, Buzău-sud G. 2, Ciulnița G. 1 B), to which are added the three graves (Dridu-tell G. 2, Grădiștea G. 11, Largu G. 1) belonging to female adolescents (in the case of the Sarmatian communities in Wallachia, female adolescents do not differ from the adults from the point of view of the funerary ritual and the grave goods - Oța/Sirbu/Matei 2013, 334, 335). 13 graves (Grădiștea G. 19, Lișcoteanca-Moș Filon G. 3, Lișcoteanca-Movila Olarului G. 13, Râmnicelu G. 3, G. 5, G. 9, Spiru Haret G. 1, Bucu G. 7, Ulmeni G. 4, G. 5, Jilava G. 2, Largu G. 2, Ciulnița G. 4) belonged to children (meaning $25 \%$ ) out of a total of 48 burials with Roman items for which data on the age of the deceased individuals are known.

Although the very high percentage (46, which means $64.78 \%$ ) of the graves with Roman items for which the sex of the buried individuals is unknown is discouraging, it is worth mentioning, however, that in 19 graves were buried women (Dridu-tell G. 2, Gălățui G. 3, Grădiștea G. 11, Bucu G. 8, Chiscani-sat, Călărași G. 7, Căscioarele, Târgșor G. 184, G. 198, G. 200, Ulmeni G. 3, Vitănești G. 2, Smeeni-Movila Mare G. 2, Largu G. 1, G. 7, Luciu, Oltenița-Renie G. 7, Gălățui G. 4, Ciulnița G. 1 B), and only six deceased were men (Lișcoteanca-Moș Filon G. 1, Lișcoteanca-Movila Olarului G. 7, BrăilaHipodrom G. 2, Bucu G. 10, Largu G. 6, Buzău-sud G. 2). However, the assumption that the Roman grave goods characterize 'female' burials rather than 'male' burials cannot be supported with convincing arguments at this stage of research. It is rather a general tendency observed in the case of the Sarmatian burials in Wallachia, which is: given that an anthropological analysis was carried out only for relatively few graves, it is much more difficult to suppose, based on the funerary inventory, which graves belonged to male individuals compared to which graves belonged to female individuals. The explanation is related to a possible standardization of the inventory of men's graves, which makes the items deposited less varied compared to the items found in graves that can be attributed to women, at least in the case of Wallachia (Oța/Sîrbu/Matei 2013, 335).

I have already drawn attention that the Sarmatian discoveries are not evenly distributed throughout the territory of Wallachia, but only cover certain areas (Fig. 1). Most of the graves, 121 , are concentrated in the southern and southeastern areas of Wallachia, of which Roman products were discovered in 30 graves (which means a fairly small percentage of only $24.79 \%$ ). In eight graves out of the total of 30 , the funerary inventory consisted exclusively of Roman items. However, if we take into account only the sites where Sarmatian graves with Roman items were registered, one can observe that out of a total of 42 sites with Sarmatian discoveries in the south of Wallachia, graves with Roman objects were found in 19 sites (45.23\%). The observation regarding the low number of Roman items deposited as inventory in the Sarmatian graves in Wallachia does not change radically, but it is amended by a relatively uniform territorial distribution, a fact also confirmed by the existence of four groups of graves in which the percentage of burials with Roman grave goods ranges between 100 and 50\% (Ulmeni, Gălățui, Vlad Țepeș, Oltenița-Puțul de cărămidă). Only in the case of one large groups of burials (Oltenița-Iordoc with eight burials) are the Roman grave goods completely absent. The other groups of graves without Roman items have a small number of burials (between two and four), although it is not excluded that this absence is in fact due to the way in which some of these groups were published (Oltenița-Coada Lupului, Oltenița-Valea Mare, Sultana), in which case the only certain group without Roman discoveries would remain Cetatea Veche, with two burials. The observation of the low number of Roman items deposited as funerary inventory, however still distributed relatively evenly from the territorial point of view, noted in the case of the southern area of Wallachia, remains valid for the east and northeast areas of Wallachia: from a total of 99 graves, 32 contained Roman items (32.32\%), of which eight (10 if the graves with partially recovered inventory were added) contained exclusively Roman objects. However, out of 28 sites, in 16 (57.14\%) were found graves with Roman items, and the groups that did not contain Roman items have a small number

\footnotetext{
6 Due to the few anthropological determinations, the age of the majority of the individuals buried in Sarmatian graves from Wallachia remains unknown. Sometimes, a closer look at the published pictures or drawings helps estimating if they are adults or children (for details, see Oța 2018, 41-46, tab. 3; 4). In the absence of anthropological analyzes, the deposition of a dagger or sword could be a clue that these are adult graves, because, at least for the Sarmatian graves in Wallachia or Moldavia, such weapons were never found in children graves.
} 

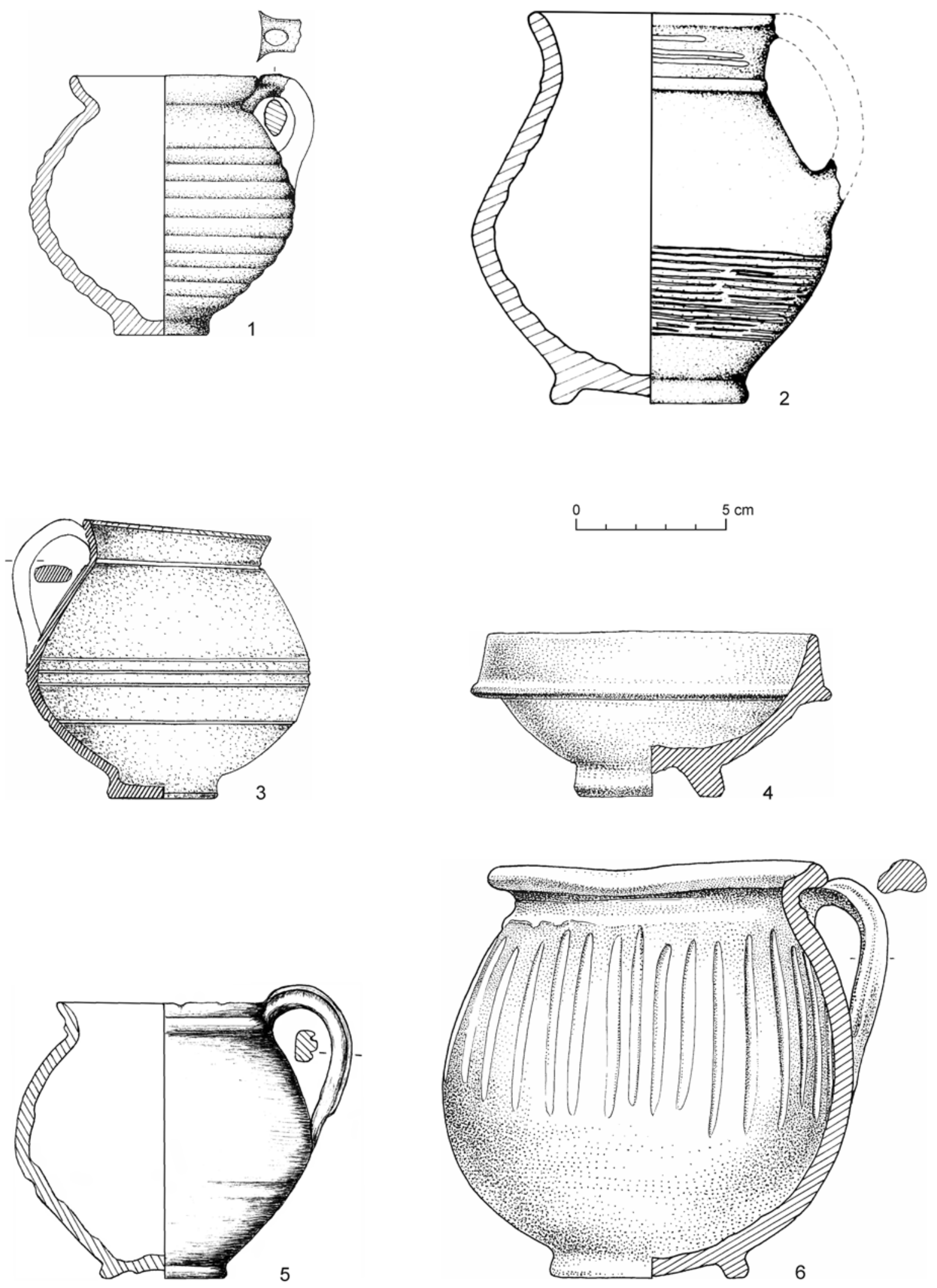

Fig. 2. Roman pottery. 1-3, 5 - mugs; 4 - cup; 6 - pot. 1, 2 - Brăila-Hipodrom G. 3 (after Oța/Sîrbu 2009); 3 - Măriuța G. 2/2009 (after Sîrbu et al. 2014); 4, 6 - Brăila-Liceu (after Oța/Sîrbu 2009); 5 - Sudiți (courtesy of Sebastian Matei, Buzău County Museum). 

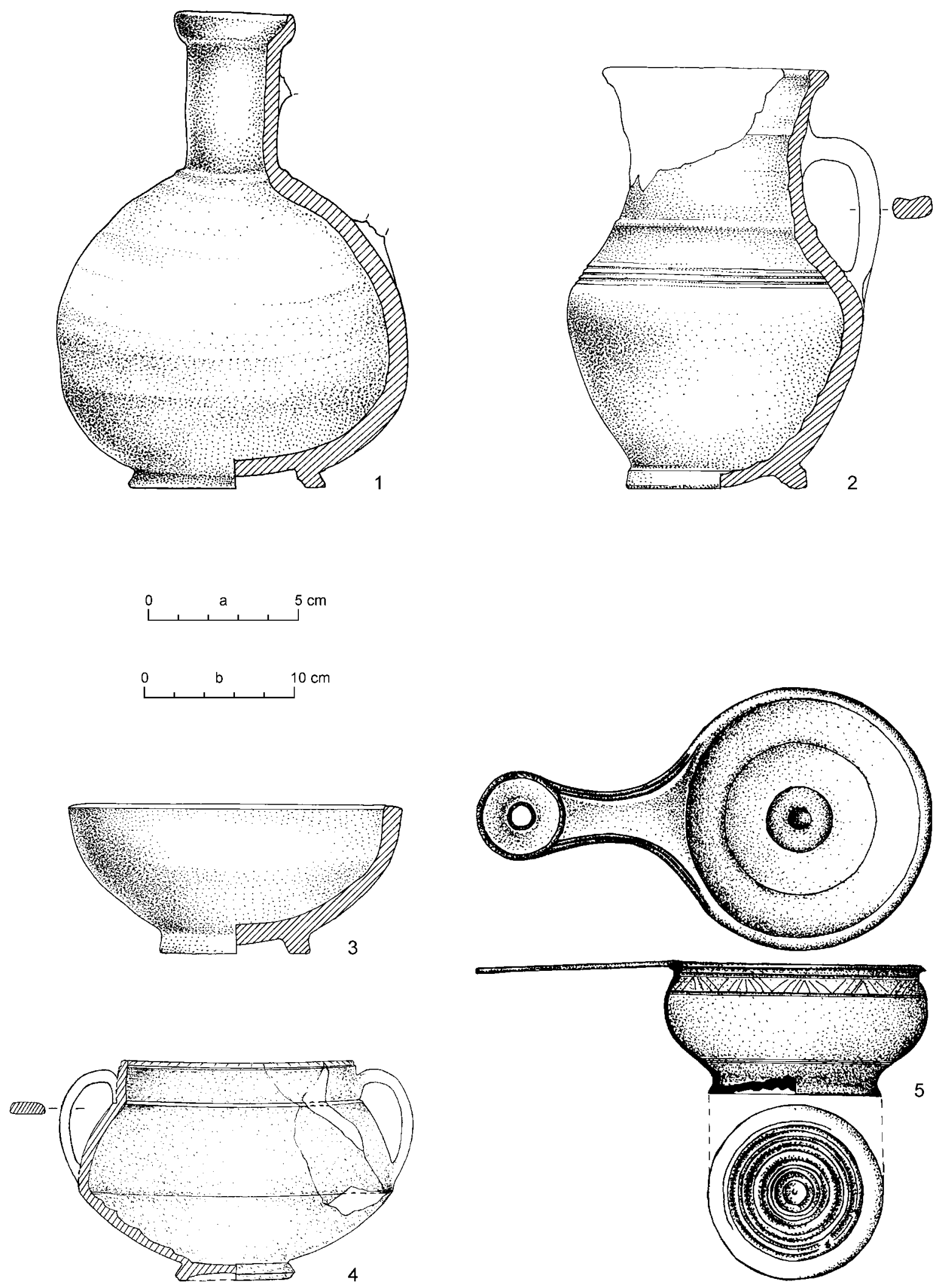

Fig. 3. Roman pottery. 1 - jug; 2 - pitcher; 3 - bowl; 4 - cup; 5 - bronze casserole. 1 - Lișcoteanca-Moș Filon G. 1 (after Oța/Sîrbu 2009); 2 - Lișcoteanca-Movila Olarului G. 7 (after Oța/Sîrbu 2009); 3 - Râmnicelu G. 14 (after Oța/Sîrbu 2009); 4 - Gura Ialomiței (after Sîrbu et al. 2014); 5 - Ulmeni (after Bichir 1977). Scale: a - 1-4; b - 5 . 

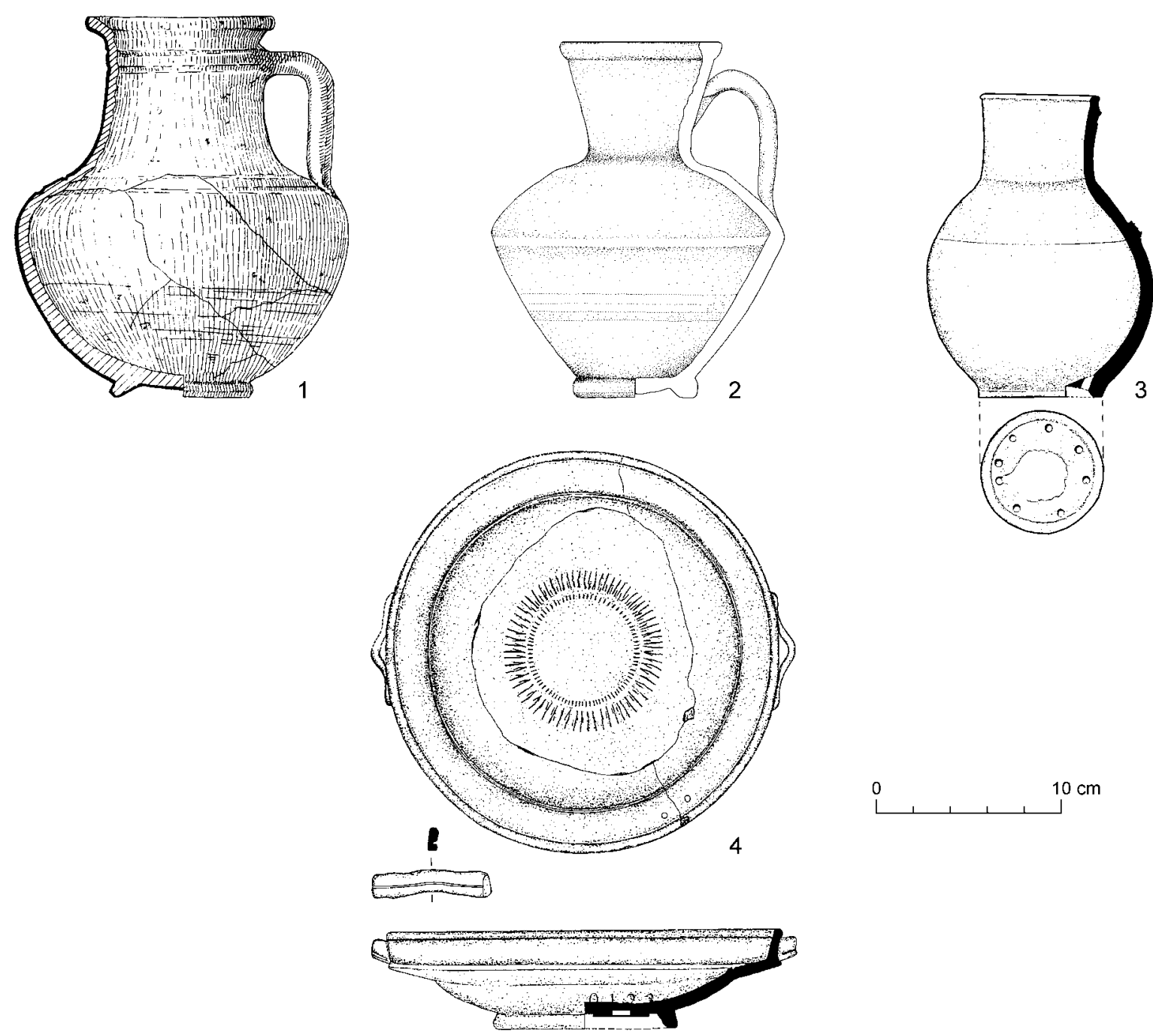

Fig. 4. Roman pottery. 1-3 - jugs; 4 - bowl. 1 - Ulmeni G. 3 (after Sîrbu et al. 2014); 2 - Luciu (courtesy of Sebastian Matei, Buzău County Museum); 3 - Bucu G. 7 (after Rența 2000); 4 - Bucu G. 10 (after Rența 2000).

of burials (three groups of burials, with a total of eight graves: Lișcoteanca-Movila din baltă, Jugureanu, Cireșu). The percentage of graves with Roman objects from the central-northern area of Wallachia is similar to that of the other areas, south and east (eight graves out of a total of 23, therefore $34.78 \%$, of which one with inventory consisting only of beads), and the two groups of burials have comparable percentages of graves with Roman items (38.8\% in Târgșor, with the amendment that the analysis took into account only the published graves, and 33.3\% in Jilava). The fourth area with Sarmatian discoveries of Wallachia is the west one, between the two lines of Roman fortifications known as limes alutanus and limes transalutanus, where only five Sarmatian graves are known, of which one (20\%) with Roman imports.

\section{Roman grave goods}

The typology of the Roman objects found in the graves and the accidental discoveries attributed to the Sarmatians in Wallachia is not very varied.

The Roman ceramic vessels were deposited in 22 graves out of the 71 burials with Roman items. The typology of the 29 ceramic vessels ( 27 deposited in graves and two that were not found in graves) shows that the most widespread import vessels were the mugs (11 burials: Brăila-Hipodrom G. 3 Fig. 2: 1, Grădiștea G. 19, Măriuța G. 2/2009 - Fig. 2: 3, Ulmeni G. 2, G. 4, Buzău-sud G. 2 and destroyed grave, Luciu, Sudiți - Fig. 2: 5, possibly also BrăilaHipodrom G. 2 and Bucu G. 14, which are added by the discoveries in Ulmeni and Oltenita-Renie, which were not found in graves), followed, in de- 


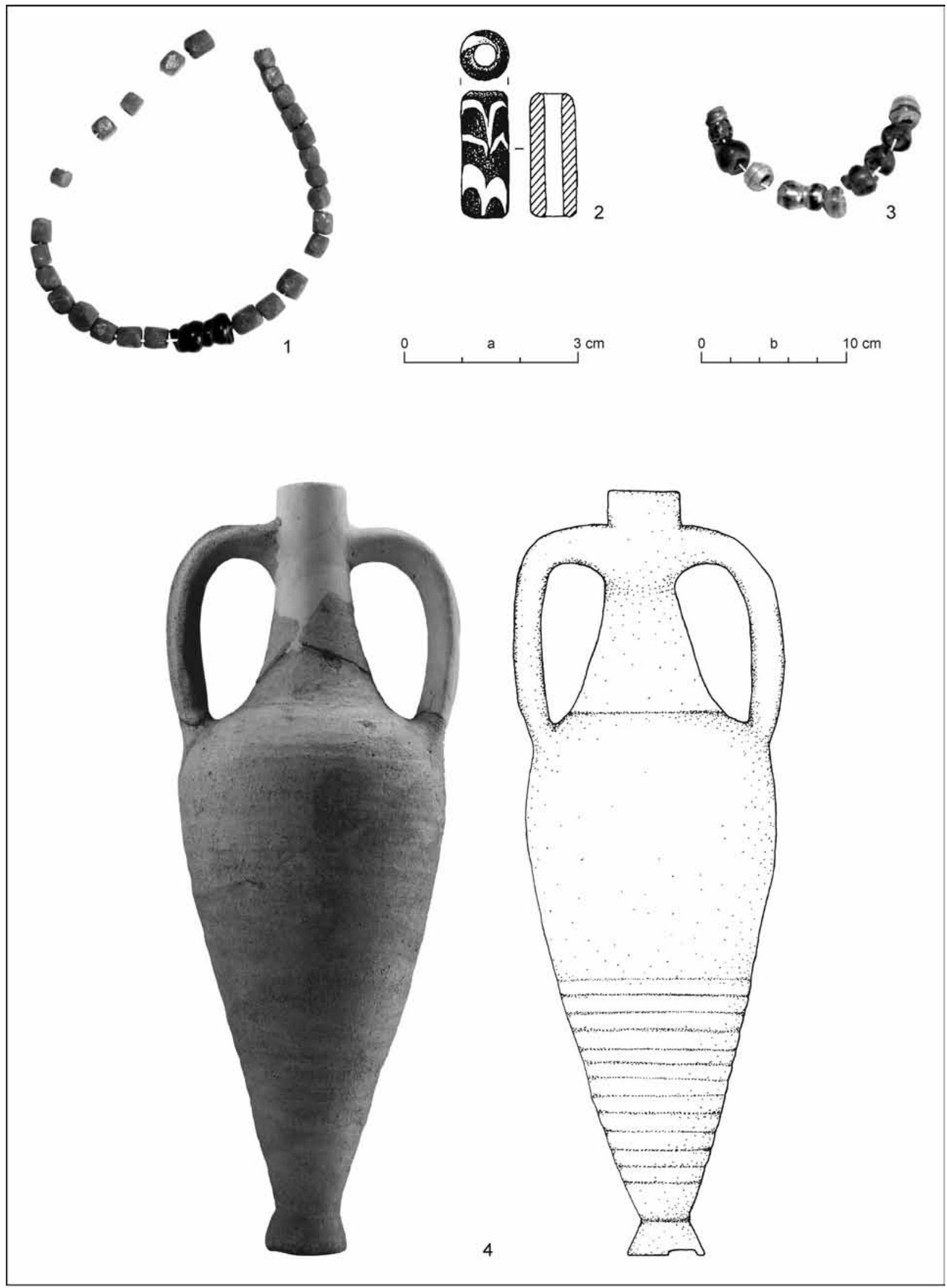

Fig. 5. 1-3 - Roman beads; 4 - amphora. 1 - Tichilești G. 4 (after Oța/Sîrbu 2009); 2 - Spiru Haret G. 1 (after Oța/Sîrbu 2009); 3 - Tichilești G. 2 (after Oța/Sîrbu 2009); 4 - Viespești (after Oța/Sîrbu/Grosu 2012). Scale: a - 1-3; b - 4. 


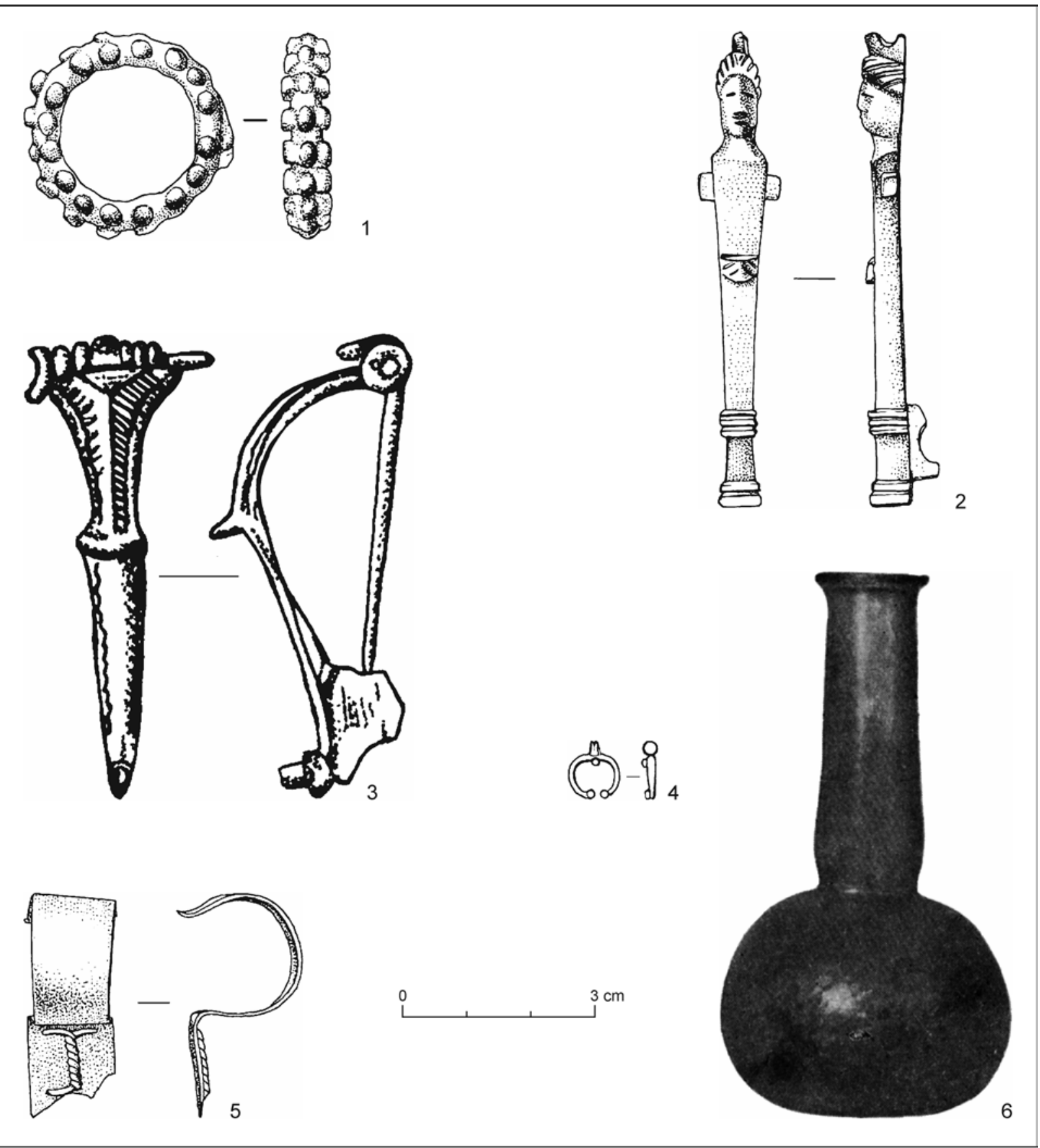

Fig. 6. 1-5 - Roman metal objects; 6 - glass objects. 1, 2 - Mohreanu (after Oța/Sîrbu 2009); 3 - Ulmeni G. 1 (after Sîrbu et al. 2014); 4 - Râmnicelu G. 14 (after Oța/Sîrbu 2009); 5 - Lișcoteanca-Moș Filon G. 3 (after Oța/Sîrbu 2009); 6 - Ulmeni (after Morintz/Ionescu 1968). Without scale - 6.

scending order, by jugs (four cases: Lișcoteanca-Moș Filon G. 1 - Fig. 3: 1, Ulmeni G. 3 - Fig. 4: 1, Bucu G. 7 - Fig. 4: 3, and Luciu - Fig. 4: 2), bowls (three: Râmnicelu G. 14 - Fig. 3: 3, Bucu G. 10 - Fig. 4: 4, one grave in Târgșor), pots (three: Brăila-Liceu - Fig. 2: 6, Jilava G. 2, one grave in Târgșor), cups (two: Brăila-Liceu - Fig. 2: 4, and Gura Ialomiței - Fig. 3: 4), amphoras (two: Vitănești G. 2 and Viespești - Fig. 5: 4) and pitchers (two: Lișcoteanca-Movila Olarului
G. 7 - Fig. 3: 2 and one grave in Târgșor). The rule of depositing only one Roman vessel in a grave knows two exceptions: Brăila-Liceu (where two such vessels were discovered, pot and cup, the latter being used as a lid) and Luciu (Roman mug and Roman jug, associated with a Dacian bowl).

The vessels manufactured from materials other than ceramic are few. The bronze casserole (Fig. 3: 5) and the glass unguentarium (Fig. 6: 6) from Ulmeni 
are accidental discoveries about which it cannot be said with certainty whether or not they originate from destroyed graves. At first glance, the number of funerary structures in which glass vessels were discovered amounts to two, but a careful analysis shows that, in fact, none of these burials is exempt from doubts. The fragments of glass vessels in G. 2 from Vitănești do not belong to the original inventory of the grave, but to the medieval robbers, so that they can be rightly excluded from among the Roman grave goods. A glass vessel is mentioned in the inventory of G. 7 from Oltenița-Renie (Morintz) Ionescu 1968, 100, 101; 1970, 39, 43, 45), but the photo to which reference is made in the text is that of the unguentarium from Ulmeni, so that a confusion between the two sites cannot be excluded. However, despite the doubts, I have decided to keep the mention of a glass vessel in the inventory of the G. 7 from Oltenita-Renie, for two reasons. The first is that the authors of the discovery specify a glass vessel among the grave goods of G. 7 from Oltenița-Renie in both studies in which they published the discoveries from Oltenița (Morintz/Ionescu 1968, 100; 1970, 39). A glass vessel of the same type is also recorded in the inventory of a Sarmatian grave found in the region between the Carpathians and the Prut, more precisely in G. 14 from Isaiia (Ursulescu/Kogălniceanu 2002-2004, 33, 34), and this is another reason why the mention of the glass vessel in G. 7 from OltenițaRenie should not be rejected a priori.

Apparently, the number of graves in which adornment items were discovered is a large one ( 55 graves out of 71 ). The appearance is due to the fact that beads made of glass or amber were found in all the 55 graves, alone or in association with other adornment items. Two observations should be made from the beginning regarding the abovementioned types of beads. The exclusively Roman origin of the glass beads has long been called into question (Laser/Voß 1994, 7) and is still a topic of debate. However, attention should be drawn to the fact that the archaeological evidence of a possible production of glass beads in the Barbaricum is still absent, at least for the early Roman period (Meyer 2013, 61, 62, 70; Tempelmann-Mączyńska 1985, 108, $133,134) .{ }^{7}$ Judging strictly from a geographical perspective and knowing all of the grave goods from the Sarmatian graves in Wallachia, it is dif- ficult to assume that these communities procured such adornments elsewhere than from the Roman markets, thus explaining the frequency of depositing glass beads in the graves. Given that evidence of glassware workshops in the Dacian environment is absent, the glass beads must have been brought from other more remote regions, which would have increased their value, including if used as funerary inventory. On the contrary, at least in the case of the Sarmatians in Wallachia, the glass beads are some of the most widespread grave goods, including in graves of children, being often the only inventory in a burial. Although the source of raw material for the amber beads originates from northern Europe, at least during the first three centuries $A D$, their processing was carried out in Roman workshops, of which the most famous were those from Aquileia or the present-day Cologne (Przybyła/Rydzewska 2019, 168).

Returning to the functionality of the beads, if we look carefully at the position of the beads in the graves, we can see that one can speak of the beads worn as adornments, more precisely necklaces or bracelets, only in 33 cases: Brăila-Liceu, Chiscani-sat (Fig. 7: 5), Grădiștea G. 11 (Fig. 7: 2, 6), Lișcoteanca-Moș Filon G. 3 (Fig. 8: 2, 3), G. 6 (Fig. 8: 7), Lișcoteanca-Movila Olarului G. 13, Râmnicelu G. 3 (Fig. 8: 5, 8), G. 5 (Fig. 8: 1, 4, 6), G. 9, Spiru Haret G. 1 (Fig. 5: 2), Tichilești G. 2 (Fig. 5: 3), G. 4 (Fig. 5: 1), Măriuța G. 2/2009 (Fig. 7: 3, 4), Ulmeni G. 3, G. 4, Bucu G. 8, Călărași G. 7 (Fig. 7: 1), Gălățui G. 3, Oltenița-Renie G. 1, Unirea, Dridu-tell G. 2, Largu G. 1, G. 2, G. 7, Târgșor G. 184, G. 198, G. 206, G. 267, Ciulnița G. 1 B, possibly also Râmnicelu G. 14, Căscioarele, Chirnogi, and Largu G. 5. ${ }^{8}$ For the remaining cases either the position of the beads was unknown (nine graves: Grădiștea G. 19, Mohreanu, Ulmeni G. 1, G. 29 , G. 5, Călărași G. 2, Oltenița-Puțul de cărămidă G. 1, Ulmu, Păuleasca G. 57), or it can be assumed that the beads only decorated the attire or the accessories, which means that they rather fall into the category of the dress accessories (11 cases: Bucu G. 10, Ciulnița G. 4, Gălățui G. 4, Vitănești G. 2, Oltenița-Renie G. 7, G. 9, Vlad Țepeș G. 2, Largu G. 6, G. 8, Smeeni-Movila Mare G. 2, Târgșor G. 200, G. 253, to which could be added G. 228 from Târgșor, where the beads were found near the feet, but in a robbery pit). Adornments made of beads

\footnotetext{
7 The same observation of a supposed large-scale manufacturing of glass bracelets, but with the lack of concrete evidence of glass workshops during Latène period was made for the Lower Rhine region, for example (Roymans 2007, 485).

8 Assumption supported by the association between beads and pendants.

9 Unlike other graves containing beads whose material was not specified, which were excluded, the beads found in G. 2 from Ulmeni were considered as Roman items. The main reason consists in the fact that, although the material from which the beads were made was not specified in the description of the grave, only beads made of amber, glass or metal were mentioned in the inventory of the burials found in Ulmeni (Morintz/Ionescu 1968, 110; 1970, 41). The probability that the beads from G. 2 are Roman products is high, given the frequency of Roman objects at Ulmeni.
} 


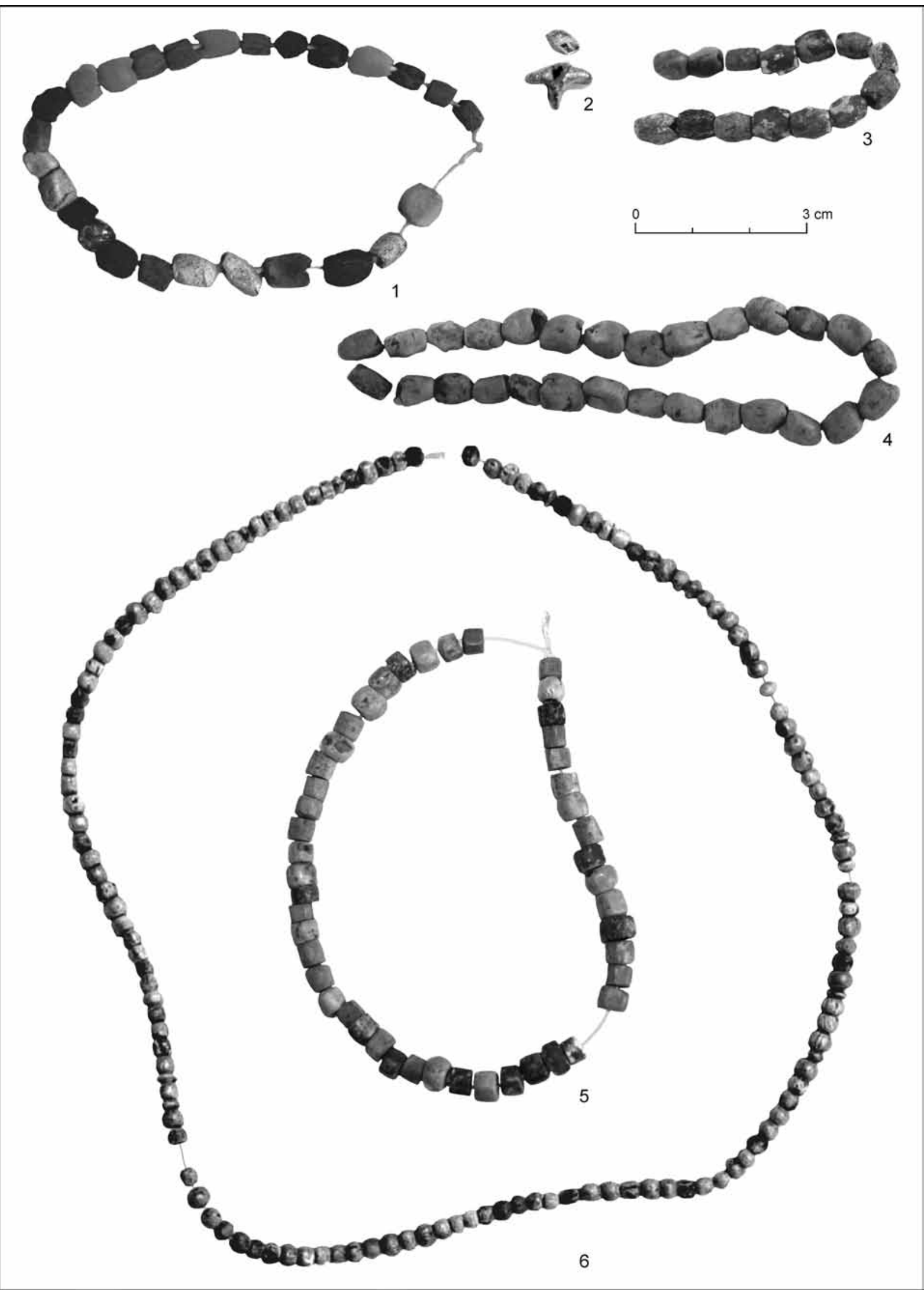

Fig. 7. Roman beads. 1 - Călărași G. 7 (after Sîrbu et al. 2014); 2, 6 - Grădiștea G. 11 (after Oța/Sîrbu 2009); 3, 4 - Măriuța G. 2/2009 (after Sîrbu et al. 2014); 5 - Chiscani-sat (after Oța/Sîrbu 2009). 


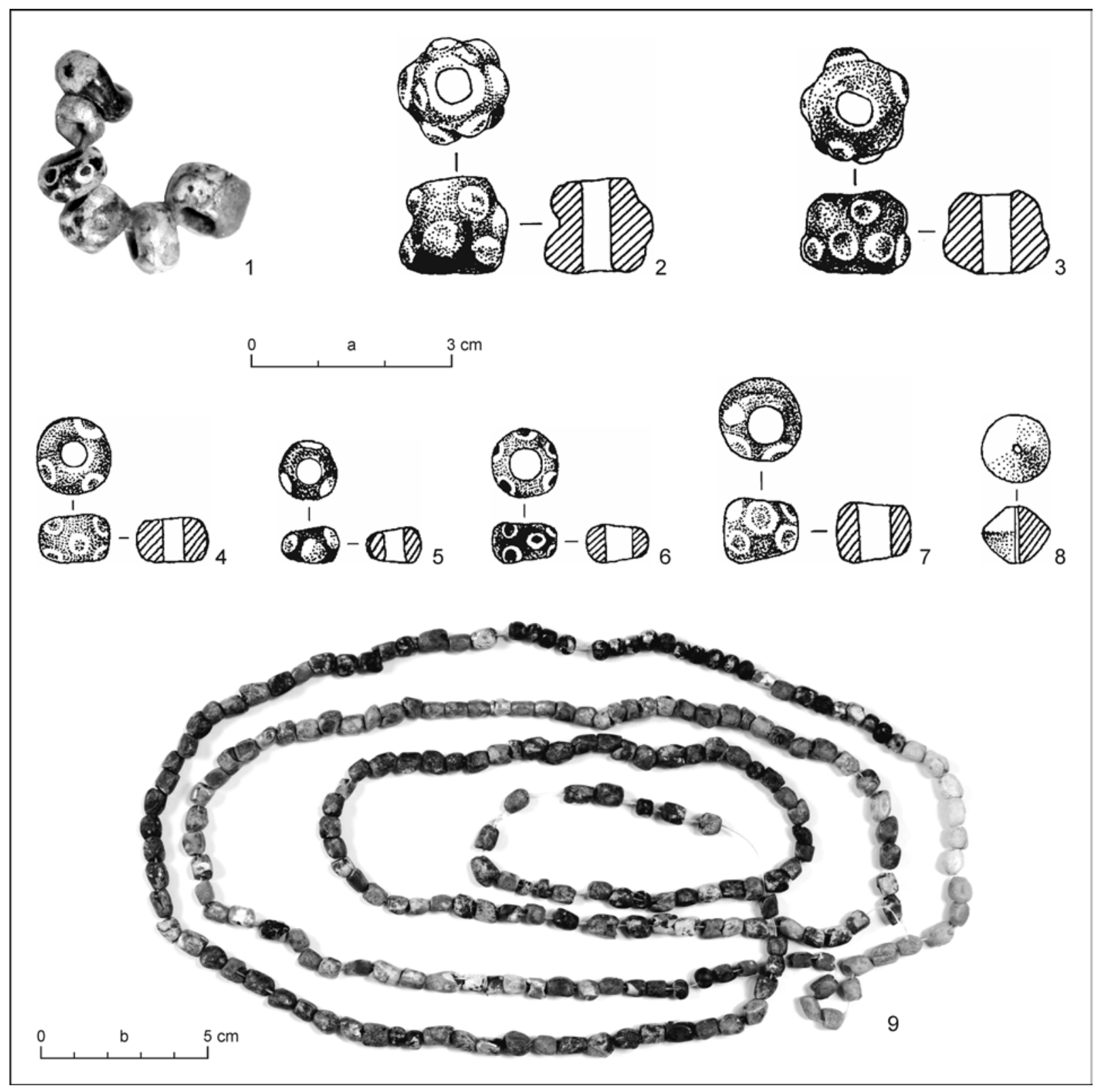

Fig. 8. Roman beads. 1, 4, 6 - Râmnicelu G. 5 (after Oța/Sîrbu 2009); 2, 3 - Lișcoteanca-Moș Filon G. 3 (after Oța/Sîrbu 2009); 5, 8 - Râmnicelu G. 3 (after Oța/Sîrbu 2009); 7 - Lișcoteanca-Moș Filon G. 6 (after Oța/Sîrbu 2009); 9 - Vitănești G. 2 (after Sîrbu et al. 2014). Scale: $\mathrm{a}-1-8 ; \mathrm{b}-9$.

and attire decorated with beads were found in 13 graves (Grădiștea G. 11, Măriuța G. 2/2009, Ulmeni G. 3, Bucu G. 8, Gălățui G. 3, Dridu-tell G. 2, Largu G. 1, G. 2, G. 7, Târgșor G. 184, G. 198, G. 267, Ciulnița G. 1 B). Usually, the beads were worn as adornments or they were dress accessories, which means that they were not intentionally deposited as grave goods, but their presence is rather owed to the close connection with the body of the deceased (Berg 2002, 15, 16). There are however two cases in which the beads were not only worn by the deceased individuals as adornments or dress decorations, but they were intentionally deposited as grave goods in ceramic vessels (Călărași G. 7 and Târgșor G. 184). It is also worth mentioning the association in two cases (Bucu G. 10 and Largu G. 6) of the beads with weapons, which could prove that sometimes even the male accessories, most probably belts (Vaday/ Istvánovits/Kulcsár 1989, 112), were decorated with one bead (made of bronze, found near the left forearm at Bucu and made of glass, in the right shoulder area, at Largu).

Apart from the beads, the adornment items of Roman origin found in the Sarmatian graves in 


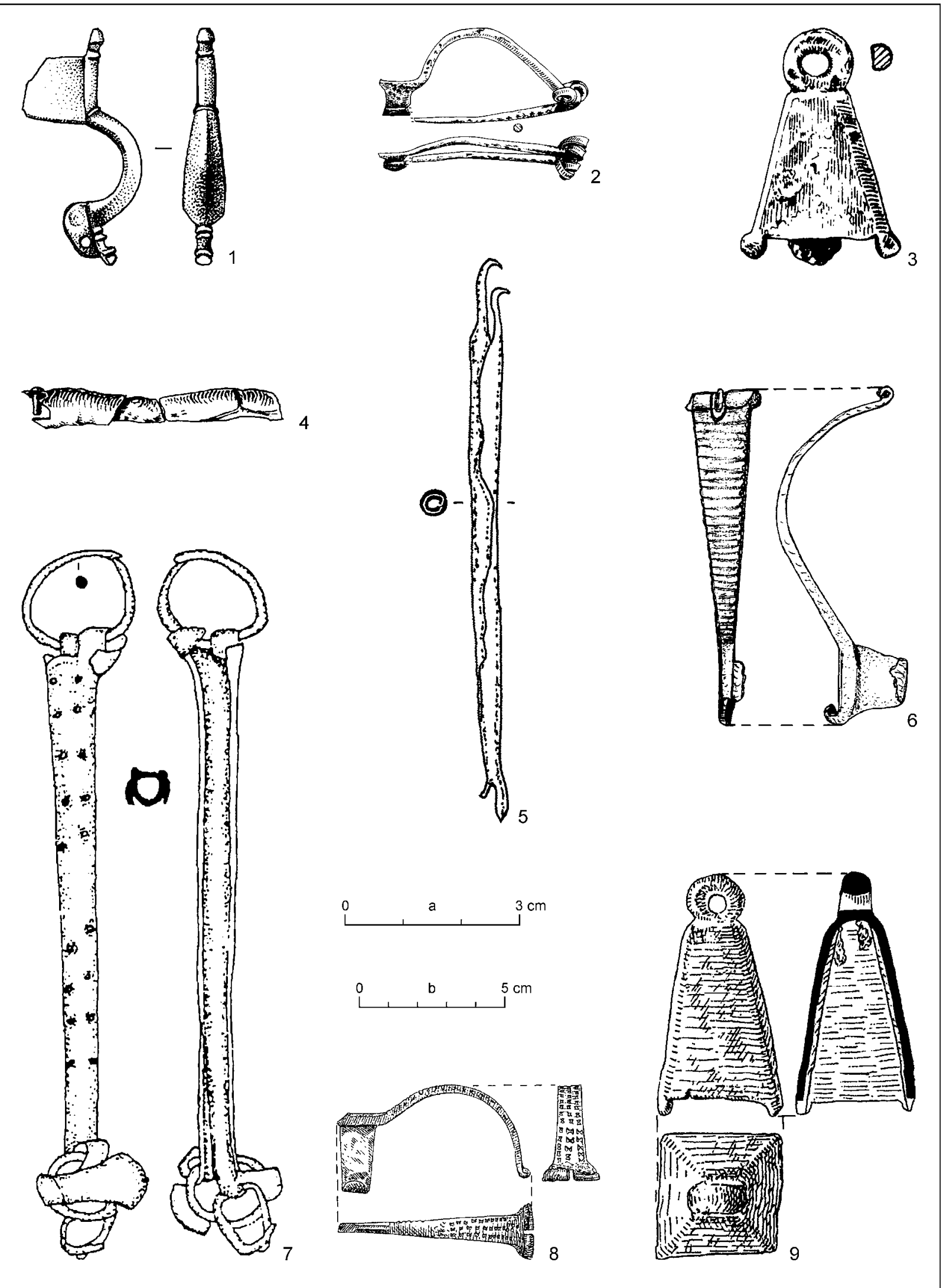

Fig. 9. Roman metal objects. 1 - Chiscani-sat (after Oța/Sîrbu 2009); 2-4 - Luciu (after Drâmbocianu 1974); 5 - Ciulnița G. 1B (after Sîrbu et al. 2014); 6 - Călărași G. 7 (after Rența 2016); 7 - Bucu G. 8 (after Rența 2000); 8, 9 - Căscioarele (after Morintz 1960). Scale: $a-1,3-9 ; b-2$. 
Wallachia consist of a bronze earring (Grădiștea G. 19), a gold pendant (Râmnicelu G. 14 - Fig. 6: 4) and bronze bells (Nowakowski 1988, 111-114), found in five graves: Ulmeni G. 3, Căscioarele (Fig. 9: 9), Largu G. 1, G. 10, Luciu (Fig. 9: 3), to which is added a bell in Ulmeni about which no information on the discovery context has been published (Sîrbu et al. 2014, 83, no. 3). Although there are opinions according to which the lunula pendants from the Pannonia Plain are North-Pontic products (Vaday 1982-1983, 174; Vaday 1988-1989, 55), I kept the half-moon pendant in G. 14 from Râmnicelu among the Roman items because both the typological characteristics ${ }^{10}$ and the analogies of the item under discussion plead in favour of a provenance rather from the Empire than from the North-Pontic areas (Oța/Sîrbu 2009, 54, 55, no. VIII A 32). The classification of the bells among the adornment items could raise doubts at first glance. There are two arguments in favor of this classification: the position inside the grave (in the neck area in G. 1 and G. 10 from Largu, at the base of the left lung in G. 3 from Ulmeni, the only exception being the funerary structure from Luciu, where, according to the discoverers, the bell was found between the feet, as the position of the bell from Căscioarele is unknown) and the association with the beads (Ulmeni G. 3, Căscioarele and Largu G. 1). The above-mentioned adornments are added by the bronze ring from Oltenița-Renie, whose discovery context is unknown.

According to the above analysis, the number of Sarmatian graves in Wallachia in which were discovered adornments manufactured in the Roman Empire decreases from 55 to 35 . To the 33 graves in which the beads could be counted as adornments are added two more graves, in which an earring (Grădiștea G. 19), and a bell (Largu G. 10) were discovered..$^{11}$ As in the case of the ceramic vessels, the Roman adornments were also found one in each grave (with the possible exception of G. 19 in Grădiștea, where an earring associated with glass beads, whose position is unknown), because the pendant and the bells associated with the beads could be assumed with high probability as accessories of the string worn around the neck.

The image of the Roman items known in the Sarmatian environment in Wallachia is completed by three graves in which brooches were discovered, all belonging to the strongly profiled type-Dorobanțu G. 1, Ulmeni G. 1 (Fig. 6: 3) and Smeieni-sat (for the typological classification, analogies and dating, see the discussion in Sirbu et al. 2014, 42, 43, no. 16.2 for Dorobanțu, and 77, no. 41.6 for Ulmeni). According to the typology of K. Hellström $(2018,82,83)$, they belong to type IIB.2 (kräftig profilierte Fibeln ohne Stützplatte), widespread on the territory of Romania and dated especially in the second half of the $1^{\text {st }} \mathrm{c}$. AD. Unfortunately, the brooch from Smeieni-sat it is not described or illustrated, but only briefly mentioned. Although in some previous contributions I regarded the brooches of G. 7 from Călărași (Fig. 9: 6) and Căscioarele (Fig. 9: 8) as belonging to the Aucissa type, in the typology of the brooches found in the northern area of the Black Sea elaborated by Kirsten Hellström, such brooches are classified as type VA (Scharnierbogenfibeln mit spitzdreieckigem Blechbügel Alesia und Derivate), variant 3 (massiver spitzdreieckiger Blechbügel und Spiralfußende - Hellström 2018, 197, kat. 34, pl. 56/34.12, from Tyras for the brooch in G. 7 from Călărași and 197, Kat. 35, Taf. 56/35, from Berezan, for the brooch from Căscioarele), whose origin does not yet reach consensus, as the opinions vary between a Roman, North-Pontic or North-Caucasian production (Cocis 2004, 76; Hellström 2018, 97-99). The item from Luciu (Fig. 9: 2) is a late Latène type brooch (Hellström 2018, 211, kat. 197, pl. 26/197.2, from Krasnyj Majak, belonging to type IC.2a-Bogenfibeln mit Drahtbügel und Fußendknopf), whose origin is still subject of debate (Cocis 2004, 40; Rustoiu 1997, 42). Given the uncertainties, the three brooches from Căscioarele, Călărași G. 7 and Luciu are regarded as items whose Roman origin is not sure. Equally uncertain is the Roman origin of the brooch from Chiscani-sat (Fig. 9: 1), a product of the workshop from Porolissum, where artisans of German origin worked and the production was directed to the Barbaricum (Cociș/ Bârcă 2014, 204, type B2b1a1, and 207). Called into question is also the Roman origin of the appliqué (Fig. 6: 5) in G. 3 from Lișcoteanca-Moș Filon (Oțal Sîrbu 2009, 41, 42, no. VI A 22).

Links with knobs made of bronze were discovered in the graves from Mohreanu (Fig. 6: 1) and Dridu-tell. As it was an accidental discovery, the functionality of the item from Mohreanu cannot be known with certainty, because according to the analogies from the Pannonia Plain, such links could have been worn on necklaces, bracelets, belts, but also on the finger (Vaday 1988-1989, 58). The link in G. 2 from Dridu-tell was found bound to the iron bracelet on the right forearm as a result of corrosion,

\footnotetext{
${ }^{10}$ M. Párducz $(1941,164,165)$ points out that the rib is characteristic of the North-Pontic workshops and the simple wire of the Roman workshops.

11 The position of the bell found at Luciu and the fact that it was not associated with any other types of adornments (beads or pendants) raise doubts regarding its classification as adornment and this is the reason why, at least for the moment, I have preferred to exclude it. The lack of any type of adornments (especially beads) raise doubts regarding a possible function of ornamenting the long end of the belt, too (Vaday/Istvánovits/Kulcsár 1989, 112).
} 

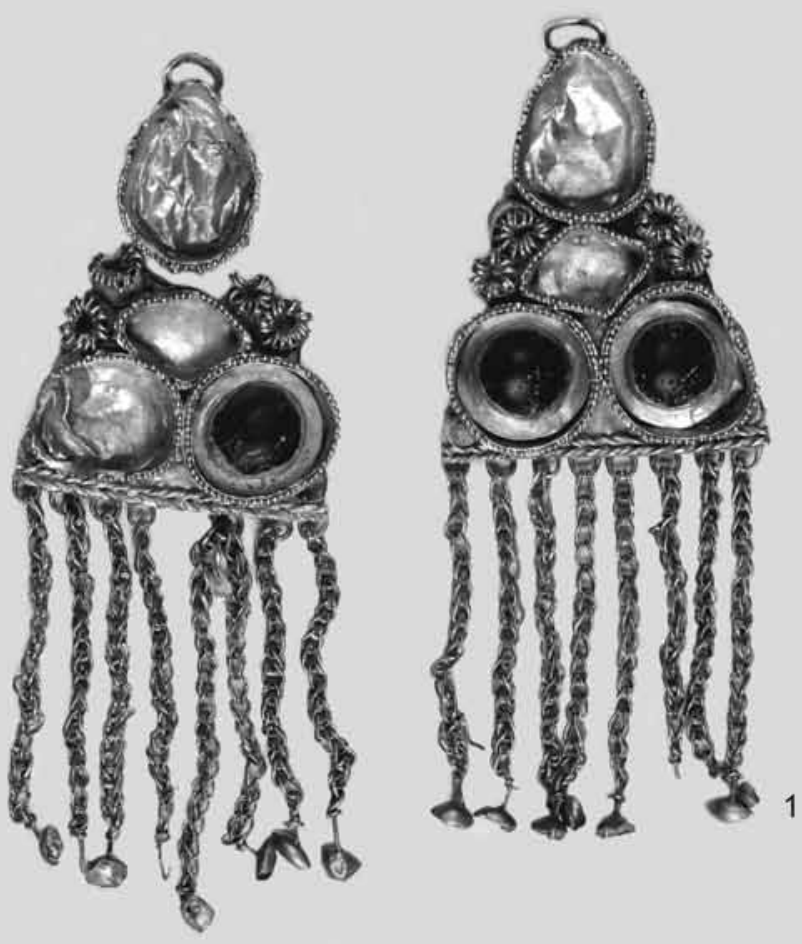

1

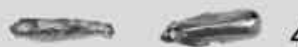

4
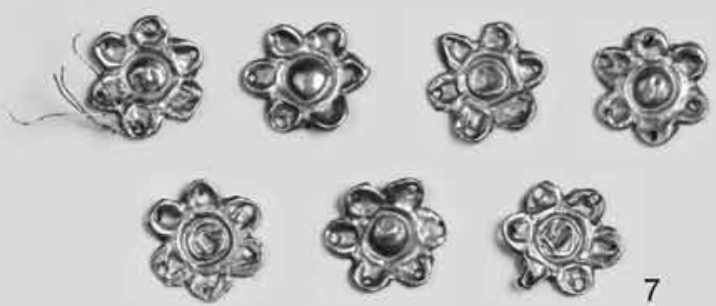

7

Fig. 10. Buzău. "The treasure from Buzău”. Gold items, most likely inventory of a grave. (after Oța/Oța 2015).

which could lead to a possible pendant, therefore to the framing in the adornments category. Opinions on their origin are divided between regarding them as products of the North-Pontic Greek workshops (Vaday 1988-1989, 59), Dacian workshops (Glodariu 1984, 71), stylistic developments of a type of ring or amulet-ring characteristic of the Spätlatènezeit Celtic culture, which are also met in the early Roman period (Schlott/Spennemann/Weber 1985, 472, 473) or items manufactured in Crimean or North-Pontic environment, but whose prototype was the same as for Dacian links with knobs (Žuravlev 2014, 80). Although at the end of the $1^{\text {st }} \mathrm{c}$. AD the Roman hegemony over the northern coast of the Black Sea and also over the Greek cities from which such items could originate was already installed, I have however excluded the links with knobs from among the Roman grave goods and also the gold adornments from the socalled 'Buzău hoard' (Fig. 10), most likely inventory of a grave belonging to a Sarmatian noble women, also products of the North-Pontic workshops (Oțal Oța 2015, 537-566). The gold adornments from the so-called 'Buzău hoard' can be considered to be expressions of a relatively local material culture, visible especially in the graves, which can be linked to the elites of the Sarmatian tribes or to the population from urban centers such as Olbia, Pantikapaion or even Tomis (Fless/Treister 2007, 180, 181). Even if the probability of their production in North-Pontic workshops is high, the rarity of the links with knobs shows that, as in the case of the adornments from the 'Buzău hoard', wearing them is rather a fashion trend that the Sarmatians from Wallachia brought along from their areas of origin and maintained in the regions 
where they settled, even if sporadically. The presence of the links with knobs is rather the last visible manifestation inside the graves of a disappearing fashion in Wallachia, and not a change of costume as a result of an influx of products of Roman origin.

Two items, one in G. 8 from Bucu (Fig. 9: 7) and the other in the grave from Luciu (Fig. 9: 4) are presumed to be remains of fans, both of the Tălmaza type (Popa 2007, 332; 2009, 81, 82; Skóra/NiezabitowskaWiśniewska 2018, 162, no. 4, 164, no. 17). The shape of the item in G. 8 from Bucu (Fig. 9: 7) is a typical one, but there are still some issues regarding the remains of a tubular bronze item with a transversal rivet at the end (Fig. 9:4), discovered in the grave from Luciu (Drâmbocianu 1974, 305, fig. 2/5). The poor conservation of the item, the absence of any elements that would make it resemble with the preserved metal parts of the fans (links, joint remains), the fact that the items does not seem to have a U-shaped section, but it is tubular, according to the description, the presence of the transversal rivet at one end are likely to call into question the framing of the item from Luciu as a fan, uncertain even in the opinion of the researcher who issued this hypothesis (Popa 2009, 81). Instead, what was described as a bronze pendant in the inventory of the female buried in G. 1 B from Ciulnița (Fig. 9: 5) could rather be the handle of a fan, made of two rolled sheets with a link at one end, although some doubts due to the state of preservation still persist. I believe that the item from Luciu should be completely excluded from the discussion about the Roman objects, given its uncertain identification. Instead, the fans in G. 8 from Bucu and G. $1 \mathrm{~B}$ from Ciulnița were however kept in the category of items with uncertain Roman origin, be it only for the possibility of representing a possible takeover of a Roman provincial fashion trend (Popa 2009, 90), although the origin of the Tălmaza type fans is rather presumed to be the North-Pontic area (Skóra/Niezabitowska-Wiśniewska 2018, 180).

Although definitely reused, the casket clasp discovered in the grave from Mohreanu (Fig. 6: 2) is certainly an item of Roman origin.

Usually, only one Roman item was discovered in the Sarmatian graves from Wallachia (54 cases for sure, to which other three uncertain could be added). The most notable presence is represented by the beads (38 graves: Chiscani-sat, Grădiștea G. 11, LișcoteancaMoș Filon G. 6, Lișcoteanca-Movila Olarului G. 13, Râmnicelu G. 3, G. 5, G. 9, Spiru Haret G. 1, Tichilești G. 2, G. 4, Ulmeni G. 5, Călărași G. 2, Ciulnița G. 4, Chirnogi, Gălățui G. 3, G. 4, Oltenița-Renie G. 1, G. 9, Ulmu, Unirea, Vlad Țepeș G. 2, Oltenița-Puțul de cărămidă G. 1, Păuleasca G. 57, Dridu-tell G. 2, Largu G. 1, G. 2, G. 5, G. 6, G. 7, G. 8, Smeeni-Movila Mare G. 2, Târgșor G. 184, G. 198, G. 200, G. 206, G. 228,
G. 253, G. 267, perhaps 42 if we do not take into account the association of beads with items of uncertain Roman origin in Lișcoteanca-Moș Filon G. 3, Bucu G. 8, Călărași G. 7 and Ciulnița G. 1 B). As frequency, beads were followed at a fairly large distance by the ceramic vessels (13 graves: Brăila-Hipodrom G. 2 and G. 3, Lișcoteanca-Moș Filon G. 1, Lișcoteanca-Movila Olarului G. 7, Gura Ialomiței, Bucu G. 7, G. 10, G. 14, Buzău-sud G. 2 and destroyed grave, Sudiţi, Jilava G. 2, Viespești), brooches (two cases: Dorobanțu G. 1 and Smeieni-sat) and bell (one grave - Largu G. 10). The combinations between several import items are rare -14 certain cases, 18 if we also count the items of uncertain Roman origin. The most common association is between ceramic vessels and beads, sometimes combined with pendants or bells (eight cases: Brăila-Liceu, Măriuța G. 2/2009, Ulmeni G. 2 and G. 4, Bucu G. 10, Vitănești G. 2, Râmnicelu G. 14, Ulmeni G. 3), followed by the combination between beads and brooch (one certain case - Ulmeni G. 1 and another two uncertain cases - Chiscani-sat and Călărași G. 7), and the association between beads and fans (Bucu G. 8, Ciulnița G. 1 B). As regards the rest of the graves, each combination is unique: beads + glass vessel (Oltenița-Renie G. 7); beads + casket clasp (Mohreanu); pottery + beads + earring (Grădiștea G. 19); pottery + bell + possibly brooch (Luciu); beads + bell + possibly brooch (Căscioarele), and beads + possibly appliqué (Lișcoteanca-Moș Filon G. 3).

The graves whose inventory consists only of Roman products are 19: 12 only beads (LișcoteancaMoș Filon G. 6, Lișcoteanca-Movila Olarului G. 13, Râmnicelu G. 5, Tichilești G. 4, Ulmeni G. 5, Călărași G. 2, Gălățui G. 3, Ulmu, Unirea, Vlad Țepeș G. 2, Largu G. 2, Târgșor G. 206), three only with ceramic vessels (Sudiți, Buzău destroyed grave, and Bucu G. 7), one with beads + casket clasp (Mohreanu), one with bell (Largu G. 10), one with pottery + beads (Măriuța G. 2/2009), one with pottery + beads + earrings (Grădiștea G. 19).

\section{The grave goods}

An overview of the grave goods deposited in the 71 graves submitted to the present analysis proves itself to be useful not only as regards the general characteristics of the burials, but also in deciphering the role that the Roman items could have played in the funerary ritual.

The most common inventory deposited in the 71 graves in Wallachia in which Roman items were found is represented by the ceramic vessels, discovered in 43 graves. In terms of frequency, the number of graves in which ceramic vessels of several traditions were deposited and the number of graves 
in which only Roman vessels were discovered is balanced: 15 in the first case and 12 in the second case. Only Roman pottery was deposited in BrăilaLiceu (Fig. 2: 4, 6), Grădiștea G. 19, Lișcoteanca-Moș Filon G. 1 (Fig. 3: 1), Lișcoteanca-Movila Olarului G. 7 (Fig. 3: 2), Râmnicelu G. 14 (Fig. 3: 3), Măriuța G. 2/2009 (Fig. 2: 3), Ulmeni G. 3 (Fig. 4: 1), Bucu G. 7 (Fig. 4: 3), G. 10 (Fig. 4: 4), G. 14, Buzău destroyed grave and Sudiți (Fig. 4: 5), although here there is a doubt regarding the destroyed grave from Buzău from which only one Roman vessel was recovered, a fact that, however, does not exclude the possibility of depositing several vessels that could no longer been preserved. In other nine graves only handmade pottery was deposited (Grădiștea G. 11, Spiru Haret G. 1, Călărași G. 7, Smeieni-sat, Ciulnița G. 4, Târgșor G. 184, G. 198, G. 267, Oltenița-Renie G. 1), and the least frequent finding is the Dacian wheel-made pottery-only six graves (Tichilești G. 2, Căscioarele, Oltenița-Renie G. 9, Largu G. 6, Smeeni-Movila Mare G. 2, Târgșor G. 253). The associations of ceramic vessels in the case of the 15 above-mentioned graves are the following, in descending order: Roman pottery and Dacian wheel-made pottery (six graves: Viespești, Luciu, Buzău-sud G. 2, Ulmeni G. 2, Brăila-Hipodrom G. 2, G. 3), handmade pottery + Dacian wheel-made pottery (five cases: Chiscanisat, Dorobanțu G. 1, Largu G. 7, Oltenița-Renie G. 7, Ulmeni G. 1), handmade pottery + Roman pottery (two cases: Jilava G. 2, Ulmeni G. 4), handmade pottery + Dacian wheel-made pottery + Roman pottery (two graves: Vitănești G. 2 and Gura Ialomiței). The vessel from G. 1 in Ciulnița is not described.

The expression 'handmade pottery' requires further explanation. Most vessels of this type have analogies in the Sarmatian environment, but there are some exceptions. The shape and decoration of the jar in G. 184 from Târgșor appear to be rather inspired from the Dacian pottery repertoire $(O t ̦ a$ 2014-2015, 100), and the two lids in G. 1 from Ulmeni have analogies within the same pottery manufacturing tradition. The careful examination of the lid in G. 3 from Cireșu (Oța/Sîrbu 2009, 100, no. 15; 155) gave opportunity for an essential observation although the shape seems to be inspired from the Dacian pottery, however, in terms of fabric, degreasers and modeling, the lid is close to the jar it covered, so that the possibility of a ceramic form manufactured by the Sarmatians according to a Dacian model should not be excluded. Analyzing the published photograph, even the handmade truncated bowl in G. 4 from Ulmeni cannot be attributed to a certain ceramic tradition, because there are analogies both in Sarmatian graves and in burials on the territory of the Roman Empire (Sîrbu et al. 2014, 81, G. 4, no. 2; 104). The handmade vessel found in the grave from
Smeieni-sat is only mentioned, without any other additional details (Bichir 1977, 171, note 30; 188). The impossibility to know with certainty, at least at the current stage of research, whether the handmade pottery discussed above were made by the Dacians or by the Sarmatians according to Dacian models, is the reason why I used the expression 'handmade pottery', without specifying 'Sarmatian' or 'Dacian'. It should be noted, however, that in the 18 graves in which handmade pottery was discovered either alone or in combination with wheel-made pottery, most of the deposited pottery forms (19 out of 25) had analogies, both in terms of shape and manufacturing, in the pottery attributed to the Sarmatians.

The number of the ceramic vessels deposited inside the graves varies between one and four. Only one vessel was deposited in 25 graves. It was most often a Roman vessel: five mugs (Grădiștea G. 19, Măriuța G. 2/2009 - Fig. 2: 3, Bucu G. 14, Buzăusud destroyed grave, Sudiți - Fig. 2: 5), three jugs (Lișcoteanca-Moș Filon G. 1 - Fig. 3: 1, Ulmeni G. 3Fig. 4: 1, Bucu G. 7 - Fig. 4:3), two bowls (Râmnicelu G. 14 - Fig. 3: 3, and Bucu G. 10 - Fig. 4: 4) and one pitcher (Lișcoteanca-Movila Olarului G. 7 - Fig. 2: 2) and less frequently (nine cases) a handmade vessel, mainly jars (Grădiștea G. 11, Spiru Haret G. 1, Călărași G. 7, Dorobanțu G. 1, Târgșor G. 184, G. 267, Ciulnita G. 4), with the two exceptions that cannot be typologically framed in the absence of the illustration (Smeeni - sat and Oltenița-Renie G. 1). Only one Dacian wheel-made vessel was discovered in six cases, most of them mugs (Tichilești G. 2, Căscioarele, Oltenița-Renie G. 9, Largu G. 6, SmeeniMovila Mare G. 2) and one jug (Târgșor G. 253). Ten graves had each two ceramic vessels deposited inside. The combination between a Roman vessel and a Dacian wheel-made vessel is the most common (four cases, all representing associations between a Roman mug and a Dacian mug: Brăila-Hipodrom G. 2, G. 3, Ulmeni G. 2, Buzău-sud G. 2), followed by the association between a handmade jar and a Dacian wheel-made mug (two graves: Chiscani-sat, Largu G. 7) or between two handmade vessels, both jars (also two cases: Ulmeni G. 1, Târgșor G. 198). The associations between two Roman vessels (cup and pot: Brăila-Liceu) and a Roman cup and a handmade jar (Jilava G. 2) are singular. Regarding G. 1 from Ulmeni, attention must be drawn to one aspect. In fact, four ceramic forms - two jars and two lids were found in the above-mentioned grave. However, the two lids were found on top of the two jars, so in my opinion we are dealing with only two recipients, both consisting of vessel + lid, and not with four different vessels. Although in the funerary structure from Brăila-Liceu the Roman cup covered the pot, I believe that we are dealing in this case with two 


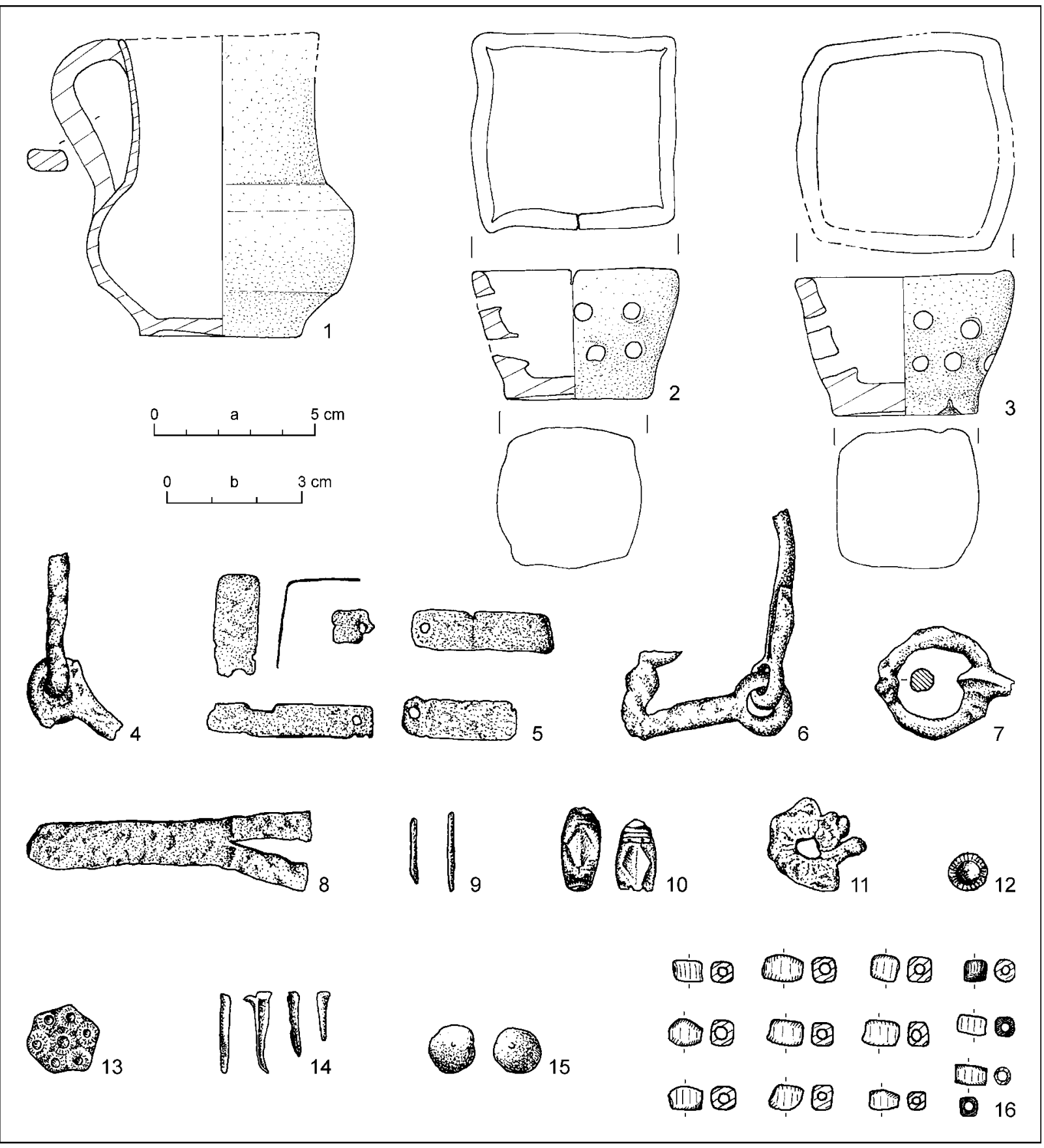

Fig. 11. Vitănești G. 2. Sarmatian elite grave. (after Sîrbu et al. 2014; Leahu/Trohani 1979). Scale: a - 1-3; b - 4-16.

different vessels (with different functions in the repertoire of the Roman vessels - Suceveanu 2000, $60,99)$, whose combination is perhaps due only to the funerary ritual, not necessarily to the role played in everyday life (Fig. 2: 4, 6). ${ }^{12}$
Much less frequent are the graves in which three ceramic vessels were deposited. The association of the vessels is the following: Roman cup (Fig. 3: 4) + Dacian wheel-made bowl + Dacian handmade jar at Gura Ialomiței, two handmade vessels (jar and

\footnotetext{
${ }^{12}$ In the absence of Sarmatian settlements in Wallachia, it would be extremely risky to make any assumptions about the role that Roman vessels could have played in everyday life - possible imitation of the Roman habit of drinking wine (Krekovič $2000,261)$ or of provincial-Roman culinary habits (Popa 2011, 215) or a simple spread of some elements of material culture (Popa 2013, 147). J. Jilek $(2015,176,183)$ draws attention to the fact that, in the case of the Germanic populations, we are dealing with a simplification rather than with an imitation of Roman dining customs.
} 
bowl) + a Roman mug in G. 4 from Ulmeni, two Dacian wheel-made vessels (mug and bowl) and a Roman amphora (Fig. 5: 4) at Viespești, and Roman jug (Fig. 4: 2) + Roman mug + Dacian bowl (Luciu). The burial from Vitănești is characterized by the presence of four ceramic vessels belonging to the three traditions (two handmade, truncated, perforated vessels - Fig. 11: 2, 3, a Dacian wheel-made mug - Fig. 11: 1 and Roman amphora). According to the original publication, seven vessels (Morintz/ Ionescu 1968, 100, 101; 1970, 39, 43, 45) were found in G. 7 from Oltenița-Renie, although only five are illustrated: two handmade jars and three Dacian wheel-made vessels, of which two mugs and one bowl (Sîrbu et al. 2014, 66, 67, nos. 1-5, with the previous bibliography).

Leaving aside the 13 graves in which the position of the ceramic vessels is unknown, 30 graves provide data for such an analysis. Where a single ceramic vessel was found, it was placed next to the skull: three Roman vessels (the jug in G. 1 from Lișcoteanca-Moș Filon and the mugs in G. 2/2009 from Măriuța and G. 14 from Bucu, all of them on the left side), three handmade vessels (all jars, in G. 11 from Grădiștea, G. 1 from Spiru Haret and G. 267 from Târgșor), and a Dacian wheel-made mug (in G. 2 from Tichilești, on the right side). Most often, the single vessel deposited in the grave was found next to the feet: four Roman vessels, three deposited on the right side (the jugs in G. 7 from LișcoteancaMovila Olarului, and G. 3 from Ulmeni, and the bowl in G. 10 from Bucu) and one on the left side (the jug in G. 7 from Bucu), four handmade vessels, three on the right side (Călărași G. 7, OltenițaRenie G. 1, Târgșor G. 184), and one on the left side (Ciulnița G. 4), three Dacian wheel-made mugs (G. 9 from Oltenița-Renie, G. 6 from Largu and G. 2 from Smeeni-Movila Mare). In the case of the graves in which two vessels were found, these were grouped either near the head, on the left side (a Dacian handmade mug and a Roman mug at Brăila-Hipodrom G. 3) or on the right side (Brăila-Liceu, where the Roman cup was found on top of the Roman pot), or at the feet (a Dacian wheel-made mug and a handmade jar at Chiscani-sat and two handmade jars in G. 1 from Ulmeni). Sometimes, the separation of the vessels concerns not only the anatomical body part next to which they were deposited: head and legs (Roman pot and handmade jar, both on the left side, in G. 2 from Jilava, two handmade jars, both on the right side, in G. 198 from Târgșor), knees and feet (Dacian wheel-made mug and the handmade jar in G. 7 from Largu), but also the body part on which they were deposited (Roman mug to the left of the head and Dacian mug near the right knee in G. 2 from Buzău-sud, Dacian wheel-made mug near the left knee and handmade jar near the right foot in G. 7 from Largu). All three vessels, two handmade (jar and bowl) and a Roman one (mug), in G. 4 from Ulmeni were found near the head, while in the burial from Luciu each of the three vessels had a different position (the Roman jug on the right of the skull, the Dacian bowl near the left foot and the Roman mug near the right foot). There are no mentions about the position of the vessels in G. 7 from Oltenița-Renie, but one can see in the published picture how four vessels were grouped at the feet and two were deposited near the head - of which one seemingly handmade on the right side, and one on the left side.

According to the analysis of the position of depositing the vessels, it is noteworthy that the vessels imported from the Roman Empire do not seem to play a special role in the funerary ritual. Regarding the value they could have been granted as possible rarities in the material culture of the Sarmatians from Wallachia, one aspect is worth mentioning the deposit in G. 7 and G. 10 from Bucu of two Roman vessels, one repaired (the bowl in G. 10 - Fig. 4: 4) and one repaired, with a changed destination (the jug in G. 7, on the basis of which there is an old crack and eight small, carefully made perforations on the edge, one of which seems to be linked to a repair, as it pairs with another perforation found on the body of the vessel-Fig. 4:3). For the moment, an explanation for the deposit of the two repaired vessels cannot be deciphered with certainty. The repair of the two vessels combined with the change in destination of one of them, initially a vessel for liquids, seems to argue in favour of the desire to keep the two vessels, which could suggest they were granted high value. Regarding their use as grave goods, it is difficult to say whether these vessels were deposited precisely because they had a special value that made the worthy of being repaired, or on the contrary, because the repair decreased their value and they were removed from everyday life instead of other unrepaired ceramic recipients.

A last aspect that must be mentioned regarding the pottery deposited in the graves with Roman objects from Wallachia is the takeover of the shape of the Roman mugs in the repertoire of the Dacian wheel-made pottery, exemplified by the mug deposited in G. 3 from Brăila-Hipodrom (Fig. 2: 2), next to a Roman mug. ${ }^{13}$

Adornment items were found in 40 graves of the 71 submitted to the present analysis. The graphic of their frequency indicates the beads in the first

\footnotetext{
${ }^{13}$ I would not go so far as to assume an adoption of Roman technology, typical case for 'immaterial imports' (Meyer 2013, 59, 62).
} 
place (33 possible cases), followed in descending order by the earrings (14 graves, two of which are uncertain), pendants (seven graves, in one of which the functionality of the item is uncertain), bracelets (six graves, including the one made of beads in G. 5 from Râmnicelu), bells (five graves) and iron link (one grave). The total number of graves in which beads are reported is 53 , but the analysis of the positions in which the beads were discovered reduces to 33 the number of burials in which these beads can be regarded as adornments, and not dress ornaments. In 18 graves, the adornments consisted only of beads (Brăila-Liceu, Grădiștea G. 11 - Fig. 7: 6, LișcoteancaMoș Filon G. 3 and G. 6 - Fig. 8: 2, 3, 7, LișcoteancaMovila Olarului G. 13, Râmnicelu G. 3 and G. 5 - Fig. 8: 1, 4-6, 8, Spiru Haret G. 1 - Fig. 5: 2, Tichilești G. 2 - Fig. 5: 3, and G. 4 - Fig. 5: 1, Măriuța G. 2/2009 - Fig. 7: 3, 4, Oltenița-Renie G. 1, Unirea, Largu G. 2, Târgșor G. 206 and G. 267, Chirnogi, Ciulnița G. 1 B), to which could be also added G. 3 from Gălățui, if the bead discovered in the thoracic area (CCA campania 2001, 140, 141) had been worn around the neck. It is worth mentioning that in all the abovementioned graves, the beads were discovered in the area of the neck, with the exception of G. 5 from Râmnicelu (Fig. 8: 1), where the beads were worn as a bracelet. G. 4 from Ulmeni can also be considered among the graves with a single adornment item (here the bronze pendant was discovered around the neck, probably as part of the beads necklace), possibly also G. 14 from Râmnicelu and G. 5 from Largu (with doubts, however, given that the position of the beads in the first case is unknown and by the fact that the beads were discovered in the area of the head in the second case, and the functionality of the bronze link as a pendant is not certain). If the two beads and the iron link in G. 9 from Râmnicelu and the beads necklace and the bell in G. 1 from Largu also represented a single adornment, then the number of graves in which only one adornment item made of beads was found amounts to 24 . The earrings were the only adornment of the deceased females buried in G. 14 from Bucu and possibly in Oltenița-Puțul de cărămidă G. 1. The image of the graves in which only one adornment was discovered is completed by the funerary structures from Gura Ialomiței (where a bracelet was discovered), Largu G. 10 (only a bell was recovered) and possibly Luciu (if the bell discovered between the feet was not actually sewn on the dress or on the belt - Fig. 9:3). Two types of adornments made of beads string and earrings were found in G. 184 from Târgșor (where the pendant was part of the beads string), Chiscani-sat, Largu G. 7, Târgșor G. 198, and Bucu G. 8, to which Grădiștea G. 19 and Păuleasca G. 57 could be added, if the beads discovered there were indeed adornments. The number of graves in which three or more types of adornments were found is four, and the sets of adornments consist in: beads string with pendant + earrings + bracelet (Călărași G. 7), possibly beads string with pendant and bell + earrings + bracelet (Căscioarele), beads string, possibly with bell + earrings + bracelet (Ulmeni G. 3) and beads + bracelet + possibly earrings + link decorated with knobs (if this was an adornment) + bronze tube (Dridu-tell G. 2). It should also be noted that preference is given to strings made of beads of several types of material (glass or glass paste, combined with amber beads, lapis lazuli, carnelian, coral, clay, stone, metal, mother-of-pearl), compared to only 18 cases (three of which were in question) in which only glass beads or glass paste were recorded.

If the two burials in which links decorated with knobs were found (whose functionality as dress accessories is uncertain) are not taken into account, then the number of graves in which dress accessories were discovered is 21 . Even in this case, the identification of the items in G. 1 from LișcoteancaMoș Filon and G. 2 from Smeeni-Movila Mare as being brooches remains doubtful, given that both items were destroyed, while the identification as a buckle of the link in G. 8 from Bucu (Sîrbu et al. 2014, 21, G. 8, no. 7) also remains an assumption. The majority of the dress accessories are brooches: 11 certain (Chiscani-sat, Ulmeni G. 1, Călărași G. 7, Căscioarele, Ciulnița G. 1 B, G. 4, Dorobanțu G. 1, Largu G. 1, Luciu, Smeieni-sat, Târgșor G. 198) and two uncertain (those above-mentioned from Lișcoteanca-Moș Filon G. 1 and Smeeni-Movila Mare G. 2). In terms of their association with typical female items such as mirrors, spindle-whorls or earrings, it seems that the brooches are rather components of the female attire (Chiscani-sat, Călărași G. 7, Căscioarele, Luciu, Largu G. 1, Târgșor G. 198, Smeeni-Movila Mare G. 2, Ciulnița G. 1 B). G. 1 from Dorobanțu and the funerary structure from Smeieni-sat cannot be regarded as proper exceptions, because the rest of the grave goods do not offer any clue about the sex of the buried individual. Other dress accessories discovered in the graves with Roman grave goods from Wallachia are the appliqués (four graves - Lișcoteanca-Moș Filon G. 3, Râmnicelu G. 14, Vitănești G. 2 and Căscioarele), buckles (Brăila-Hipodrom G. 2, Târgșor G. 198, Ciulnița G. 1 B, possibly Bucu G. 8), knobs (Vitănești G. 2, Largu G. 6), and foot gear (Largu G. 6).

Toilet implements were discovered in 16 graves and consist mainly of mirrors (15 items, one in each grave: Chiscani-sat, Grădiștea G. 11, Ulmeni G. 3, Bucu G. 8, Călărași G. 7, Ciulnița G. 1 B, OltenițaRenie G. 1 and G. 7, Dridu-tell G. 2, Largu G. 1 and G. 7, Luciu, Târgșor G. 184, G. 198 and G. 200). Unfor- 
tunately, the fact that the position of the grave goods from Mohreanu is unknown due to the accidental discovery, does not allow any kind of assumption about the functionality of the Roman bronze casket clasp (Fig. 6: 2). The fact that no other remains of the casket were discovered seems to support the hypothesis that we are dealing with a reused item, but it is impossible to identify its purpose, at least for now. Therefore, the classification of this grave good in the category of toilet implements took into account the initial destination of the item and not the one it could have possibly acquired when it belonged to the person buried at Mohreanu. Two items, from Bucu G. 8 and Ciulnița G. 1 B could be supposed as fans (Fig. 9: 5, 7).

Most of the household tools are represented by spindle-whorls, discovered in ten graves (Chiscanisat, Grădiștea G. 11, Ciulnița G. 1 B, Gălățui G. 4, Oltenița-Renie G. 7, Luciu, Smeeni-Movila Mare G. 2, Târgșor G. 184, G. 198 and G. 200), added by the knife in G. 3 from Lișcoteanca-Moș Filon.

The weapons are rare occurrences in the Sarmatian graves from Wallachia in which items from the Roman Empire were deposited: only five cases (daggers in G. 1 from Lișcoteanca-Moș Filon, G. 10 from Bucu, G. 6 from Largu and swords in G. 2 from Brăila-Hipodrom and G. 7 from Lișcoteanca-Movila Olarului). Harness items were found in G. 2 from Vitănești.

The general image of the grave goods discovered in the burials with Roman objects from Wallachia is completed with the exceptional occurrences of the shells (Râmnicelu G. 3), chalk (Râmnicelu G. 3), charcoals (Râmnicelu G. 9), knucklebone (Gura Ialomitei). The glass vessel in G. 7 from Oltenița-Renie also seems to represent, at least so far, a unique item in the inventory of the Sarmatian graves from Wallachia.

\section{THE DATING OF THE ROMAN PRODUCTS}

Largely based on the dating of the Roman objects, the chronology of the Sarmatian graves in Wallachia showed that the burials are dated to three stages, which represent as many moments of settlement of these communities in Wallachia: the late $1^{\text {st }} \mathrm{c}$. AD and the first half of the $2^{\text {nd }} c$. AD (late B2a phase and early $\mathrm{B} 2 \mathrm{~b}$ ); the late $2^{\text {nd }} \mathrm{c}$. and the first half of the $3^{\text {rd }}$ c. AD (C1 and early C2 phase); the late $3^{\text {rd }}$ c. AD (late C2 phase; Laser/Voß 1994, 10, fig. 2). 15 graves from those analyzed herein can be dated to the first stage of arrival of the Sarmatians in Wallachia: the isolated burials from Vitănești, Mohreanu, as well as the funerary structures with Roman items from the groups of graves at Râmnicelu (four graves), Lișcoteanca-Moș Filon (three graves), LișcoteancaMovila Olarului (two graves) and Ulmeni (four graves). Most of the graves with Roman items (49) are chronologically framed in the second stage of the Sarmatian settlement in Wallachia: the isolated graves from Căscioarele, Ulmu, Oltenița-Puțul de cărămidă, Dridu-tell, Luciu, Sudiți, Brăila-Liceu, Chiscani-sat, Măriuța G. 2/2009, the burials with Roman items from the groups of graves in Târgșor (seven graves published until now), Largu (seven graves), Bucu (four graves), Oltenița-Renie (three graves), Buzău-sud (two graves), Brăila-Hipodrom (two graves), Grădiștea (two graves), Ciulnița (two graves), Gălățui (two graves), Chirnogi (at least one grave), Vlad Țepeș (one grave), Păuleasca (one grave), Jilava (one grave), Călărași G. 7-10 (one grave), Dorobanțu (one grave), Ulmeni (one grave), Smeeni-Movila Mare (one grave), added by G. 2 from Călărași. Other two funerary structures (Smeieni-sat and Gura Ialomiței) can be dated, at least so far, only during the $2^{\text {nd }} \mathrm{c}$. $\mathrm{AD}$, without the possibility of a connection with the first or the second stage of Sarmatian settlement in Wallachia. Four burials (Viespești, Spiru Haret G. 1, Tichilești G. 2 and G. 4) are among the latest Sarmatian burials in Wallachia. The dating of the grave in Unirea remain, so far, impossible to know precisely. As regards the items of Roman origin that were not found in the graves, they can be dated either to the end of the $1^{\text {st }} \mathrm{c}$. AD and the beginning of the following century (the bronze casserole and the glass unguentarium from Ulmeni - Fig. 3: 5; 6: 6, possibly also the bronze ring from Oltenița-Renie), or to the second half of the $2^{\text {nd }} \mathrm{c}$. or during the $3^{\text {rd }} \mathrm{c}$. $\mathrm{AD}$ (the mugs from Oltenița-Renie and Ulmeni, the bell from Ulmeni). At first sight, the relevance of the Roman items for the chronology of the Sarmatian graves in which they were deposited might seem doubtful. Andrea Vaday points out that especially during the later periods, the barbarian markets, less selective than the Empire markets, could have also received old-fashioned goods, which could often result in a framing of the goods produced in the Empire in a so-called 'secondary chronological system' (Vaday 1982-1983, 168). In the case of the Sarmatian discoveries from Wallachia, the fact that they consist only of graves can bring about an additional difficulty, because an intentional choice to deposit inside the graves items that were used for a long time is not excluded. Unfortunately, the fact that no settlements have yet been identified that can be attributed to the Sarmatians and that can provide a term of comparison from the point of view of the inventory with the burials, does not allow, at least so far, any assumption regarding the possible dura- 
Table 2. Sarmatian burials with Roman products (first stage).

\begin{tabular}{|c|c|c|c|c|c|c|c|c|c|c|}
\hline No. & Grave & Pottery & $\begin{array}{l}\text { Glass } \\
\text { vessel }\end{array}$ & $\begin{array}{l}\text { Bronze } \\
\text { vessel }\end{array}$ & Beads & Pendant & Ring & Brooch & Appliqué & $\begin{array}{l}\text { Casket } \\
\text { clasp }\end{array}$ \\
\hline 1. & Lișcoteanca-Moș Filon G. 1 & $\mathrm{x}$ & - & - & - & - & - & - & - & - \\
\hline 2. & Lișcoteanca-Moș Filon G. 3 & - & - & - & $x$ & - & - & - & $?$ & - \\
\hline 3. & Lișcoteanca-Moș Filon G. 6 & - & - & - & $x$ & - & - & - & - & - \\
\hline 4. & Lișcoteanca-Movila Olarului G. 7 & $x$ & - & - & $x$ & - & - & - & - & - \\
\hline 5. & Lișcoteanca-Mov. Olarului G. 13 & - & - & - & $x$ & - & - & - & - & - \\
\hline 6. & Mohreanu & - & - & - & $x$ & - & - & - & - & $\mathrm{x}$ \\
\hline 7. & Râmnicelu G. 3 & - & - & - & $x$ & - & - & - & - & - \\
\hline 8. & Râmnicelu G. 5 & - & - & - & $x$ & - & - & - & - & - \\
\hline 9. & Râmnicelu G. 9 & - & - & - & $x$ & - & - & - & - & - \\
\hline 10. & Râmnicelu G. 14 & $x$ & - & - & $x$ & $x$ & - & - & - & - \\
\hline 11. & Ulmeni G. 1 & - & - & - & $\mathrm{x}$ & - & - & $x$ & - & - \\
\hline 12. & Ulmeni G. 2 & $x$ & - & - & $x$ & - & - & - & - & - \\
\hline 13. & Ulmeni G. 4 & $x$ & - & - & $x$ & - & - & - & - & - \\
\hline 14. & Ulmeni G. 5 & - & - & - & $x$ & - & - & - & - & - \\
\hline 15. & Vitănești G. 2 & $x$ & - & - & $x$ & - & - & - & - & - \\
\hline 16. & Ulmeni & - & $\mathrm{x}$ & $\mathrm{x}$ & - & - & - & - & - & - \\
\hline 17. & Oltenița-Renie & - & - & - & - & - & $\mathrm{x}$ & - & - & - \\
\hline
\end{tabular}

tion of the interval in which the Roman items were used. It is sure that, in the case of the Sarmatian discoveries from Wallachia, some Roman objects were used for a certain period of time. While in the case of the ceramic vessel in G. 10 from Bucu (Fig. 4: 4) the possibility of an accident that could have led to the breaking of the vessel relatively soon after its purchase cannot be excluded, regarding the jug in G. 7 from Bucu (whose destination seems to have been changed after the repair - Fig. 4: 3) and especially the bronze casserole from Ulmeni (Fig. 3:5) whose stamp has been erased, these are evidence of a longer use. Yet, the fact that the Roman items found in the Sarmatian graves from Wallachia are, with very few exceptions, common goods without special value, is an argument that may invalidate the above-mentioned observation regarding the time lag between the goods used on the Roman territory and those used in a barbarian environment, because the products with a high financial value are usually the ones preferred for long-term storage. Even if such a usage gap did exist in the case of Wallachia, it was probably not a long one, especially since most of the Roman pieces known so far in the above-mentioned region are items that were used in a wide chronological range also in the Roman Empire.

Also, with regard to the chronology of the Sarmatian burials with Roman grave goods from Wallachia, additional attention should be drawn to one aspect. The simple comparison of the figures of the Sarmatian graves with Roman grave goods dated to the first (15 graves), the second (49 graves) and the third (four graves) stages of Sarmatian settlement in Wallachia could lead to the conclusion of a mas- sive increase (a tripling, according to the figures) of the flow of Roman imports in the chronological interval that begins in the late $2^{\text {nd }} \mathrm{c}$. AD and extends also over the first part of the next century. In reality, the explanation concerns the number of Sarmatian graves that were dated to those periods. The total number of graves that can be dated to the first stage Sarmatian settlement in Wallachia amounts to 53 or 54 (Oța/Sîrbu 2016a, 262), which means that the 15 graves with Roman objects represent $27.77 \%$. The number of burials that can be dated to the second stage of Sarmatian settlement in Wallachia is 153, which means that the percentage of graves with Roman items does not exceed 33\%. The conclusion is the same: the deposit of items of Roman origin in the Sarmatian graves from Wallachia remains in both stages a small size phenomenon, which also remains unchanged to the late $3^{\text {rd }} \mathrm{c}$. AD, when the percentage of graves with Roman items is around 33\%.

\section{The procurement of the Roman products}

I have previously mentioned that the Roman ware from the Sarmatian environment in Wallachia is, for the most part, common ware, without special financial value. Overall, the Roman objects consist of ceramic vessels, adornments (such as glass or amber beads, a bronze earring, bells of the same material, a bronze ring and a gold pendant), dress accessories (brooches and beads that adorned the garment), glassware (which may in fact be only packaging of perfumes or scented oils, so that in this case the significance lays rather in the content- 
Table 3. Sarmatian burials with Roman products (second stage).

\begin{tabular}{|c|c|c|c|c|c|c|c|c|}
\hline No. & Grave & Pottery & Glass vessel & Beads & Earring & Bells & Brooches & Fans \\
\hline 1. & Brăila-Hipodrom G. 2 & $\mathrm{x}$ & - & - & - & - & - & - \\
\hline 2. & Brăila-Hipodrom G. 3 & $\mathrm{x}$ & - & - & - & - & - & - \\
\hline 3. & Brăila-Liceu & $x x$ & - & $x$ & - & - & - & - \\
\hline 4. & Bucu G. 7 & $x$ & - & $\mathrm{x}$ & - & - & - & - \\
\hline 5. & Bucu G. 8 & - & - & $x$ & - & - & - & $x$ \\
\hline 6. & Bucu G. 10 & $x$ & - & $?$ & - & - & - & - \\
\hline 7. & Bucu G. 14 & $x$ & - & - & - & - & - & - \\
\hline 8. & Buzău-sud G. 2 & $\mathrm{x}$ & - & - & - & - & - & - \\
\hline 9. & Buzău-sud destroyed G. & $x$ & - & - & - & - & - & - \\
\hline 10. & Călărași G. 2 & - & - & $x$ & - & - & - & - \\
\hline 11. & Călărași G. 7 & - & - & $\mathrm{x}$ & - & - & $?$ & - \\
\hline 12. & Căscioarele & - & - & $\mathrm{x}$ & - & $x$ & $?$ & - \\
\hline 13. & Chirnogi & - & - & $x$ & - & - & - & - \\
\hline 14. & Chiscani-sat & - & - & $x$ & - & - & $?$ & - \\
\hline 15. & Ciulnița G. 1 B & - & - & $\mathrm{x}$ & - & - & - & $\mathrm{x}$ \\
\hline 16. & Ciulnița G. 4 & - & - & $x$ & - & - & - & - \\
\hline 17. & Dorobanțu G. 1 & - & - & - & - & - & $x$ & - \\
\hline 18. & Dridu-tell G. 2 & - & - & $x$ & - & - & - & - \\
\hline 19. & Gălățui G. 3 & - & - & $x$ & - & - & - & - \\
\hline 20. & Gălățui G. 4 & - & - & $x$ & - & - & - & - \\
\hline 21. & Grădiștea G. 11 & - & - & $x$ & - & - & - & - \\
\hline 22. & Grădiștea G. 19 & $x$ & - & $x$ & $x$ & - & - & - \\
\hline 23. & Jilava G. 2 & $\mathrm{x}$ & - & - & - & - & - & - \\
\hline 24. & Largu G. 1 & - & - & $x$ & - & $x$ & - & - \\
\hline 25. & Largu G. 2 & - & - & $x$ & - & - & - & - \\
\hline 26. & Largu G. 5 & - & - & $x$ & - & - & - & - \\
\hline 27. & Largu G. 6 & - & - & $\mathrm{x}$ & - & - & - & - \\
\hline 28. & Largu G. 7 & - & - & $x$ & - & - & - & - \\
\hline 29. & Largu G. 8 & - & - & $x$ & - & - & - & - \\
\hline 30. & Largu G. 10 & - & - & - & - & $x$ & - & - \\
\hline 31. & Luciu & $x x$ & - & - & - & $\mathrm{x}$ & $?$ & - \\
\hline 32. & Măriuța G. 2/2009 & $x$ & - & $x$ & - & - & - & - \\
\hline 33. & Oltenița-Puțul de cărămidă G. 1 & - & - & $x$ & - & - & - & - \\
\hline 34. & Oltenița-Renie G. 1 & - & - & $x$ & - & - & - & - \\
\hline 35. & Oltenița-Renie G. 7 & - & $\mathrm{x}$ & $\mathrm{x}$ & - & - & - & - \\
\hline 36. & Oltenița-Renie G. 9 & - & - & $\mathrm{x}$ & - & - & - & - \\
\hline 37. & Păuleasca G. 57 & - & - & $x$ & - & - & - & - \\
\hline 38. & Smeeni-Movila Mare G. 2 & - & - & $x$ & - & - & - & - \\
\hline 39. & Sudiți & $\mathrm{x}$ & - & - & - & - & - & - \\
\hline 40. & Târgșor G. 184 & - & - & $\mathrm{x}$ & - & - & - & - \\
\hline 41. & Târgșor G. 198 & - & - & $x$ & - & - & - & - \\
\hline 42. & Târgșor G. 200 & - & - & $x$ & - & - & - & - \\
\hline 43. & Târgșor G. 206 & - & - & $\mathrm{x}$ & - & - & - & - \\
\hline 44. & Târgșor G. 228 & - & - & $\mathrm{x}$ & - & - & - & - \\
\hline 45. & Târgșor G. 253 & - & - & $x$ & - & - & - & - \\
\hline 46. & Târgșor G. 267 & - & - & $x$ & - & - & - & - \\
\hline 47. & Târgșor unpublished graves & $x x x$ & - & - & - & - & - & - \\
\hline 48. & Ulmeni G. 3 & $x$ & - & $x$ & - & $x$ & - & - \\
\hline 49. & Ulmu & - & - & $x$ & - & - & - & - \\
\hline 50. & Vlad Țepeș G. 2 & - & - & $x$ & - & - & - & - \\
\hline 51. & Oltenița-Renie & $x$ & - & - & - & - & - & - \\
\hline 52. & Ulmeni & $x$ & - & - & - & $x$ & - & - \\
\hline
\end{tabular}


Krekovič 2011, 83), a bronze casserole, a casket clasp and maybe fans and an appliqué. The separation of the types of Roman ware based on the three stages of Sarmatian settlement in Wallachia could refine to some extent this observation. In the first stage (late $1^{\text {st }} \mathrm{c} . \mathrm{AD}$ and the first decades of the $2^{\text {nd }} \mathrm{c}$.), the Roman objects in the Sarmatian environment from Wallachia (Table 2) consist of ceramic vessels, deposited in six graves (the amphora in G. 2 from Vitănești, the jug in G. 1 from LișcoteancaMoș Filon - Fig. 3: 1, the pitcher in G. 7 from Lișcoteanca-Movila Olarului - Fig. 3: 2, the bowl in G. 14 from Râmnicelu - Fig. 3: 3, the mugs in G. 2 and G. 4 from Ulmeni), also beads, discovered in 13 graves (Lișcoteanca-Moș Filon G. 3 - Fig. 8: 2, 3, G. 6 - Fig. 8: 7, Lișcoteanca-Movila Olarului G. 13, Mohreanu, Râmnicelu G. 3 - Fig. 8: 5, 8, G. 5 - Fig. 8: 1, 4, 6, G. 9, G. 14, Ulmeni G. 1, G. 2, G. 4, G. 5 and Vitănești - Fig. 8: 9), a gold pendant in G. 14 from Râmnicelu (Fig. 6: 4), the casket clasp from Mohreanu (Fig. 6: 2), the brooch in G. 1 from Ulmeni (Fig. 6: 3), the glass unguentarium (Fig. 6: 6) and the bronze casserole (Fig. 3: 5) from Ulmeni, the ring from Oltenița-Renie and possibly the appliqué in G. 3 from Lișcoteanca-Moș Filon (Fig. 6: 5). The cup from Gura Ialomiței (Fig. 3: 4) and the brooch found in the grave from Smeieni-sat are dated to the $2^{\text {nd }} \mathrm{c}$. $\mathrm{AD}$, without possibility to connect them with the first or the second stage of Sarmatian settlement in Wallachia.

The structure of the Roman items in the Sarmatian graves from Wallachia dated to the end of the $2^{\text {nd }} \mathrm{c}$. AD and the first half of the following century does not change fundamentally (Table 3). The typology of the ceramic vessels, deposited in at least 15 graves, is almost the same as in the previous stage: jugs in Bucu G. 7 (Fig. 4: 3), Ulmeni G. 3 (Fig. 4: 1) and Luciu (Fig. 4: 2), pitcher in Târgșor, bowls in Bucu G. 10 (Fig. 4: 4) and Târgșor, mugs in G. 2 and G. 3 from Brăila-Hipodrom (Fig. 2: 1), G. 19 from Grădiștea, G. 2/2009 from Măriuța (Fig. 2: 3), G. 14 from Bucu, G. 2 and destroyed grave from Buzău-sud, Luciu, Sudiți (Fig. 2: 5), cup in Brăila-Liceu (Fig. 2: 4), except the appearance of pots (Brăila-Liceu - Fig. 2: 6, Jilava G. 2 and Târgșor) instead of amphoras. The mugs accidentally found at Ulmeni and Olteniţa-Renie are also of Roman origin. Beads, discovered in 37 burials, continue to be the most widespread Roman import: BrăilaLiceu, Chiscani-sat (Fig. 7: 5), Grădiștea G. 11 (Fig. 7: 2, 6) and G. 19, Măriuța G. 2/2009 (Fig. 7: 3, 4), Ulmeni G. 3, Bucu G. 8, Călărași G. 2 and G. 7 (Fig. 7: 1), Chirnogi, Ciulnița G. 1 B, G. 4, Gălățui G. 3 and G. 4, Căscioarele, Oltenița-Renie G. 1, G. 7, G. 9, Ulmu, Vlad Țepeș G. 2, Oltenița-Puțul de cărămidă G. 1, Păuleasca G. 57, Dridu-tell G. 2, Largu G. 1,
G. 2, G. 5, G. 6, G. 7, G. 8, Smeeni-Movila Mare G. 2, Târgșor G. 184, G. 198, G. 200, G. 206, G. 228, G. 253, G. 267. In case there is no confusion with Ulmeni, in G. 7 from Oltenița-Renie was deposited a glass vessel, also manufactured in the Roman workshops. A certain Roman origin has only the brooch from G. 1 in Dorobanțu, while the fibulas from Luciu (Fig. 9: 2), Chiscani-sat (Fig. 9: 1), Călărași G. 7 (Fig. 9: 6), and Căscioarele (Fig. 9: 8) could be manufactured in barbarian workshops. Compared to the first stage of Sarmatian settlement, the image of the Roman products from the second stage also includes the earring from Grădiștea G. 19, the bells from Largu G. 1 and G. 10, Ulmeni G. 3, Căscioarele (Fig. 9: 9), Luciu (Fig. 9: 3), and the bell with unknown context from Ulmeni, possibly also the fans in G. 8 from Bucu (Fig. 9: 7) and Ciulnița G. 1 B (Fig. 9: 5). Very few Roman items, such as the beads in G. 1 from Spiru Haret (Fig. 5: 2), G. 2 (Fig. 5: 3) and G. 4 (Fig. 5: 1) from Tichilești and the amphora from Viespești (Fig. 5: 4) are registered in Wallachia at the end of the $3^{\text {rd }} \mathrm{c}$. AD (Table 4).

Table 4. Sarmatian burials with Roman products (third stage).

\begin{tabular}{|c|c|c|c|}
\hline No. & Grave & Pottery & Beads \\
\hline 1. & Spiru Haret G. 1 & - & $\mathrm{x}$ \\
2. & Tichilești G. 2 & - & $\mathrm{x}$ \\
3. & Tichilești G. 4 & - & $\mathrm{x}$ \\
4. & Viespești & $\mathrm{x}$ & - \\
\hline
\end{tabular}

The typology of the Roman products consisting only of ceramics, adornments or dress accessories and exceptionally, glass or bronze vessels, casket clasp, possibly fans, and their reduced typological variety, corroborated with the absence of truly valuable items (metal vessels, precious metal adornments), are indications of the way these goods reached the Sarmatian milieu from Wallachia. The hypothesis of trade is the most appropriate explanation for the way the Roman products reached Sarmatian communities from Wallachia, as there are no arguments, at this point, to support other possible explanations such as robbery, stipends or diplomatic gifts. Trade activities belong preponderantly to the so-called 'cross-border trade' (Hrnčiarik/ Kuzmová 2016, 150), usually in the area of Roman fortifications, through which usual vessels and other small products were circulated (Gabler 1976, 87, 88; Hrnčiarik/Kuzmová 2016, 150-152; Krekovič 1987, 278; Vaday 2005, 19), less to long-distance trade (Hrnčiarik/Kuzmová 2016, 152, 153), due to their low value. The fact that the Sarmatians settled in Wallachia not as enemies, but as allies of the Romans 
and under their supervision (asserted by BogdanCătăniciu 1983, 83; 1997, 139, 140, and argued by Oța 1999, 887; 2007, 51-53; 2016, 131-135; Oța/Sîrbu 2013, 291), is likely to offer additional explanations. Most likely, these are numerically reduced communities, whose settlement in Wallachia took place in connection with the stages of the establishment of the Danubian limes, especially in areas where they could be easily supervised by Roman garrisons, and who arrived in this area not so much as military allies, but rather for reasons related to supplying the Roman military units (Oța 2016, 135, 138; Oța/Sîrbu 2019a, 149-157). The status of Wallachia within the chronological interval between the end of the $1^{\text {st }} \mathrm{c}$. AD and the end of the $3^{\text {rd }} \mathrm{c}$. AD helps in understanding the numerical situation of the Sarmatian burials in the analyzed region, more precisely the ratio between the relatively few discoveries of burials that can be dated to the first stage of Sarmatian settlement in Wallachia and the tripling of the number of these burials during the second stage. The end of the $2^{\text {nd }} \mathrm{c}$. AD and the first half of the following century represent a period of strengthening of the Roman control over Wallachia (Oța 2016, 145; Oța/Sîrbu 2019a, 156, 157, with previous literature, nuanced approach Oța 2020, 423, $424,427,428$ ), which most likely resulted in the settlement of a higher number of Sarmatian communities in Wallachia, although it must be underlined that this phenomenon is not accompanied by an increase in the intensity of the exchange relations with the Romans, at least judging from the point of view of the funerary discoveries. The abrupt decrease in the number of Roman products discovered in the Sarmatian graves dated to the late $3^{\text {rd }} \mathrm{c}$. AD is, in turn, a consequence of the fact that, by the middle of the century, the Romans seem to lose control over Wallachia, whose archeological landscape reports several changes (Oța 2016, 145, 146; 2020, 421, 422, 424, 428-431; Oța/Sîrbu 2013, 293; $2019 a, 157)$. The reason why the exchange relations between the Sarmatians and the Romans remain low despite the geographical proximity and the control that the Romans exercise over Wallachia is a question whose answer cannot be deciphered at this moment. The limited nature of the data we have mainly on the funerary discoveries, added by some accidental discoveries, may be one of the explanations - it is not excluded that only the number of the Roman items deposited inside the graves is low, and not the number of the products from the Empire used in daily life. Another explanation could be related to the pastoral nomadic (Honeychurch/Makarewicz 2016, 343-348; Kradin 2015, 42-56; Wendrich/Barnard 2008, 7) way of life that the ancient authors associate, almost without exception, with the populations of the Eurasian steppes, which favour tableware made of other materials (wood, maybe even leather - Kradin 2015, 53) over the breakable (Krekovič 2000, 262) ceramic vessels and in which wealth is expressed not so much by the accumulation of material goods, but by the number of the animals in possession (Hauser 2006, 12; Istvánovits/Kulcsár 2013, 195; Khazanov 1981, 145, 149; Kradin 2015, 43-45).

\section{THE ROLE OF THE ROMAN ITEMS IN THE SARMATIAN GRAVES FROM WALLACHIA}

The conclusion that emerged from the discussion about the characteristics of the Sarmatian burials with Roman grave goods is that the analyzed graves do not have particular features regarding the layout of the grave, the funerary ritual or the treatment of the inventory deposited compared to the rest of the graves in which no items produced on the Roman territory were found. The burials with Roman items as grave goods do not seem to occupy a special territorial place within the group of graves to which they belong and their layout and funerary inventory is similar with that of the rest of the burials from the same group. From this perspective, it should be emphasized that even the features that, at first glance, seem exceptional (other positions of the deceased than extended supine position, for example) do not represent the only deviations within the group, being also registered for graves without Roman objects. The presence or absence of Roman items seems to be the only difference regarding the funerary inventory, since neither the number nor the type of grave goods is different. Roman objects were found in graves both of adults and children, which might mean that there is no special connection between depositing Roman products as grave goods and biological or social age. The fact that in a certain group Roman items are deposited only in adults graves (as in Târgșor) does not necessarily imply that children do not have access to Roman products (at least from the funerary point of view), but is rather related to the age ratio ( 15 out of the 18 published graves from Târgșor belong to adults and only three to children). In the case of a balanced age ratio, as in Râmnicelu (eight children graves and seven adults graves), three out of the four graves with Roman grave goods belong to children. However, a possible tendency to connect the age with a certain category of Roman products (children and beads, as in the previous example of Râmnicelu) is contradicted by other children graves where the Roman items were 
represented by pottery (Bucu G. 7 or Jilava G. 2), or pottery associated with beads (Grădiștea G. 19, Ulmeni G. 4). Unfortunately, we cannot know, at least for now, if there was a social difference, in the case of children graves, between the burials with Roman grave goods and those without such items (the inventory of G. 19 from Grădiștea consists only of Roman objects, but G. 12 from the group, also belonging to a child, does not have any grave goods, for example).

The few cases that will be discussed hereinafter are no exception to the rule, but the analysis of the archaeological context of Wallachia in that period and the association of certain funerary features indicate a much more nuanced picture regarding the status of some of the individuals buried in the funerary structures with Roman items. We have analyzed on other occasion (Oța/Sîrbu 2019b, in press) the Sarmatian graves from Wallachia that can be connected with the elites or the members with privileged status of these communities. There are two graves from the first stage of Sarmatian settlement in Wallachia, those from Vitănești and Mohreanu, both containing items of Roman origin, that betray two different ways of displaying the elite status. In the case of G. 2 from Vitănești (Fig. 11), the status is emphasized by raising a tumulus, by burying the woman with garments adorned with golden appliqués (Fig. 11: 9-13), by an unusual accumulation - not necessarily valuable but purely numerical - of grave goods, among which harness items (Fig. 11: 4, 6; Oța/Sîrbu/Matei 2013, 336, 337). The Roman amphora does not have in this case a special significance by itself (it could be only a package for wine, for example - Vaday 2005, 10, 14 - if it would be entirely deposited ${ }^{14}$ ), but rather as part of a funerary inventory that includes vessels belonging to three different traditions: handmade Sarmatian perforated vessels (Fig. 11: 2, 3), wheel-made Dacian mug (Fig. 11: 1) and Roman amphora. A completely different way of emphasizing the status is revealed by the grave from Mohreanu, by the burial in an older tumulus (therefore the choice of an elevated form of land, but sparing the effort required to raise a mound) and by a funerary inventory consisting of items possibly of North-Pontic origin (bronze link decorated with knobs - Fig. 6:1) and Roman objects (beads and reused casket clasp-Fig. 6: 2). Even if the value of the Roman items is not a special one, nevertheless, the reuse and especially the uniqueness, so far, of the bronze casket clasp pleads in favour of a special significance given to this grave good. In the general context of the archaeological discoveries from the northern Lower Danube, the fact that, at least so far, they are unique or very rare findings, may be an argument in favour of framing the bronze casserole (Fig. 3:5) and the (content of) the glass vessel (Fig. 6: 6) from Ulmeni in the so-called 'luxury goods' (Khazanov 2019, 88; Pitts 1989, 55; Rogers 2007, 253) category, although such discoveries are more common in other areas (Kraskovská 1981, 377-392; Krekovič 1987, 276; Popa 2015, 158-161; Simonenko 2011, 70-87; 2013, 98-127, especially 108-115; Simonenko/Marčenko/Limberis 2008, 21-28). The fact that in G. 14 from Râmnicelu was discovered one of the few gold adornments (Fig. 6: 4) from the inventory of the Sarmatian graves from Wallachia and Moldavia puts a different light on the deposit in the same grave of a Roman bowl, testimony of a possible privileged access to the Roman items (Oțal Sîrbu 2016a, 277). This observation is supported by the fact that Roman ceramic vessels were deposited in four of the five graves with weapons from the burials with Roman grave goods from Wallachia (the exception is represented by G. 7 from Largu, where the dagger was associated with a Dacian wheel-made mug), either alone (Lișcoteanca-Moș Filon G. 1, Lișcoteanca-Movila Olarului G. 7, Bucu G. 10), or in association with Dacian wheel-made mugs (Brăila-Hipodrom G. 2). Except for G. 2 from Brăila-Hipodrom and G. 10 from Bucu, the rest of the mentioned graves are dated to the first stage of Sarmatian settlement in Wallachia, which is characterized, among others, by the arrangement of elite graves or graves that belonged to individuals with privileged status in relation to the rest of the members of the community $(O t ̦ a 2016,137)$. In the second stage of Sarmatian settlement in Wallachia (the late $2^{\text {nd }} \mathrm{c}$. $\mathrm{AD}$ and the first half of the following century), the way of displaying the status changes in the case of the Sarmatian graves not only from Wallachia, but also from the North-Pontic area in general (Mordvintseva 2016, 396-403) and in other areas, too (Jilek 2007, 179). Among the testimonies that can be invoked in support of the hypothesis of choosing a different way of emphasizing the status, it is possible to include the brooches from the burials from Căscioarele (Fig. 9: 8) and Călărași G. 7 (Fig. 9: 6). Although of uncertain Roman origin, both items have a broken needle. Unless it is an accident, the presence of two brooches that could no longer be used according to their original purpose in the inventory of two graves belonging to women, both graves with numerous and varied inventory, can be a testimony of a privileged status, a possible imitation of a fashion trend outspread at the northern

\footnotetext{
${ }^{14}$ Unfortunately, this grave was robbed, so, it is impossible to know if the fragmentary state of the amphora is the result of robbery or of an intentional breakage of the vessel during the funerals.
} 
periphery of the Sarmatian Barbaricum from the Carpathian Basin, characterized by the reuse of Roman military costume accessories (it is worth mentioning here that the Alesia-type brooches are also worn by the military - Cociș 2004, 77) in the female attire (Istvánovits/Kulcsár 2003, 236-238; Vaday 2005, 13).

Although, in some cases, the items from the Roman Empire can be counted among the status symbols used in the funerary ritual, it is nevertheless notable that they do not play this role in themselves, but in association with other features of the layout of the graves or the inventory. ${ }^{15}$ However, in most of the graves, the items from another cultural area, in the present case the Roman Empire, do not seem to have been given a special symbolic value. This assumption is argued by the presence, in the same group, of graves where weapons were associated or not with Roman objects (LișcoteancaMoș Filon, Largu), or of graves only with weapons, without Roman grave goods (Lișcoteanca-Movila Olarului, Grădiștea). Another argument is provided by G. 11 from Bucu, where the child was buried with a silver item (possibly bracelet - Sîrbu et al. 2014, 22, 23, no. 2), one of the few items of this material found in Sarmatian graves from Wallachia or Moldavia $(O t ̦ a 2018,60)$, which might prove that depositing Roman products among other grave goods was not the only way of emphasizing the status. Unlike other areas, in the particular case of the Sarmatians from Wallachia, the Roman influence had rather the role of inhibiting the display of the elite status during the funerals. The graves that can be attributed to elite individuals display this status especially in the traditional way of the North-Pontic area - paradoxically, a way also preserved in the case of the elite Sarmatian graves from the Roman province of Moesia Inferior (Oța 2016, 139, 141, 142; Oța/Sîrbu 2019b, in press) - by the erection of tumuli and the burial with adornments or gold ornaments of the garment ('the treasure from Buzău' - Fig. 10, Vitănești G. 2 - Fig. 11), the funerary structure from Mohreanu being an exception from all points of view (the choice of an already raised tumulus, the relative modest inventory). The phenomenon is a natural one, if we interpret it in terms of the control exercised by the Roman Empire over Wallachia, which did not favour the emergence of strong leaders.

\section{CONCLUSION}

Despite the reservations induced by the absence of a comparison with the situation in the settlements, the observations occasioned by the analysis of the Roman items discovered in the Sarmatian graves from Wallachia can contribute not only to complete, but also to detail or even nuance the image of some communities brought in the immediate vicinity of the Roman Empire by their settlement in a geographical space far from their area of origin. Even though these communities have retained some features characteristic of the populations that the ancient written sources identified as 'Sarmatians' (and here I am referring mainly to the pastoral nomadic way of life and to some features of the funerary ritual, such as the inhumation or the deposit inside the graves of typical items -Oța/Sirrbu 2016b, 205, 206, 221, 222), the proximity to the Danubian limes transformed them visibly, compared to the rest of the Sarmatians which remained in their areas of origin.

\section{Catalogue of the graves, stray finds and discoveries with unknown context ${ }^{16}$}

1. Brăila (Brăila County) - Hipodrom; G. 2 (Oța/Sîrbu 2009, 15, 16 no. I A 2, 94, 95 nos. I A 3, 4, 117, 191, 192, with previous bibliography); G. 3 (Oța/Sîrbu 2009, 13-15 no. I A 1, 95 no. I A 5, 117, 118, 191, 192, with previous bibliography).

2. Brăila (Brăila County) - Liceul de Chimie (today Grup școlar industrial 'C. D. Nenițescu'); G. (Oța/Sîrbu 2009, 16-20 nos. I B 3-5, 118, 191, with previous bibliography).

3. Bucu (comm. of Bucu, Ialomița County) - Pochină; G. 7 (Sîrbu et al. 2014, 19, 20, 123, with previous bibliography); G. 8 (Sîrbu et al. 2014, 20, 21, 123, with previous bibliography; Skóra/Niezabitowska-Wiśniewska 2018, 162 no. 4); G. 10 (Sîrbu et al. 2014, 21, 22, 123, with previous bibliography); G. 14 (Sîrbu et al. 2014, 24, 123, with previous bibliography).

4. Buzău (Buzău County) - sud; G. 2 (Drâmbocianu 1981, 51, 52); destroyed grave (Drâmbocianu 1981, 54).

5. Călărași (Călărași County); G. 2 (Sîrbu et al. 2014, 25 nos. 4-6 B, 125, with previous bibliography).

6. Călărași (Călărași County) - Flacăra str. and Pompierilor str. intersection; G. 7 (Sîrbu et al. 2014, 27-30 nos. 4-6 F, $124,125)$.

7. Căscioarele (comm. of Căscioarele, Călărași County) Suharna; G. (Oța 2015b, 121-134; Sîrbu et al. 2014, 31-34, 131, with previous bibliography).

8. Chirnogi (comm. of Chirnogi, Călărași County); G. (Sîrbu et al. 2014, 37, 124, with previous bibliography).

\footnotetext{
15 "The individual objects that are crucial to a given interpretation differ greatly depending on the date and circumstance of the find." remarks T. Grane $(2007,83)$.

${ }^{16}$ The catalogue represents only an auxiliary working tool, the aim of this paper being to analyze the characteristics of the graves with Roman items from Wallachia. This is the reason why I did not mention in all cases the complete list of bibliographical references regarding the discoveries, but I chose to cite, when possible, only the synthesis mentioning all the previous bibliography, sometimes added by new references. If such a synthesis was not available, I cited all the bibliographical references.
} 
9. Chiscani (comm. of Chiscani, Brăila County) - sat; G. (Oța/Sîrbu 2009, 24-27 nos. II A 8, 9, 96-98 nos. 9-11, 119,191 , with previous bibliography).

10. Ciulnița (comm. of Ciulnița, Ialomița County); T. III, G. 1 B (Barnea 1995, 282 no. 5; CCA campania 1994, 23; Rența 2016, 94); G. 4 (Barnea 1995, 282 no. 5; CCA campania 1994, 23; Rența 2016, 95, 96).

11. Dorobanțu (comm. of Dorobanțu, Călărași County); G. 1 (Sîrbu et al. 2014, 42, 43, 128, with previous bibliography).

12. Dridu (comm. of Dridu, Ialomița County) - tell (known also as Coșereni-Măgura de la Comana); G. 2 (Lazăr/ Ștefan/Vasile 2013, 68; Oța/Georgescu/Baltă 2015, 143-149; Sîrbu et al. 2014, 45-48 nos. 17, 18 B, 131, with previous bibliography; Ștefan/Dumitrașcu/Mărgărit 2012, 71, 72).

13. Gălățui (comm. of Alexandru Odobescu, Călărași County) - Movila Berzei; G. 3 (Sîrbu et al. 2014, 49, 50, 125, with previous bibliography); G. 4 (Sîrbu et al. 2014, 50, 51, 125, with previous bibliography).

14. Grădiștea (comm. of Grădiștea, Brăila County) - Mormântul Elizei; G. 11 (Oța/Sîrbu 2009, 35-39 nos. V A 19, 20, 103, 104 nos. 23, 24, 121, 122, 192-195, with previous bibliography); G. 19 (Oța/Sîrbu 2009, 31-35 nos. V A 16-18, 123, 192-195, with previous bibliography).

15. Gura Ialomiței (comm. of Gura Ialomiței, Ialomița County); G. (Sirbu et al. 2014, 51, 52, 131, with previous bibliography).

16. Jilava (comm. of Jilava, Ilfov County) - Măgura Jilavei; G. 2 (Rosetti 1934, 209).

17. Largu (comm. of Largu, Buzău County) - Cornul Malului; G. 1 (Bichir 1972, 156; 1977, 184; Dragomir 1959, 476, 477, 479; Dragomir/Croitoru 2011, 40, 41); G. 2 (Dragomir 1959, 476, 477; Dragomir/Croitoru 2011, 41); G. 5 (Dragomir 1959, 476-478; Dragomir/Croitoru 2011, 42); G. 6 (Bichir 1971, 277, 278; 1972, 141, 155; 1977, 173, 183, 184; 1985, 1169, 1170; Dragomir 1959, 476, 477, 480, 481; Dragomir/Croitoru 2011, 42, 43); G. 7 (Bichir 1972, 145; 1977, 183; 1985, 1170; Dragomir 1959, 476-481; Dragomir/Croitoru 2011, 43, 44); G. 8 (Dragomir 1959, 476-478, 481; Dragomir/Croitoru 2011, 44, 45); G. 10 (Bichir 1972, 156; 1977, 184; Dragomir 1957, 300, 304; Dragomir/Croitoru 2011, 32; Nowakowski 1988, 114).

18. Lișcoteanca (comm. of Bordei Verde, Brăila County) Moș Filon; G. 1 (Oța/Sîrbu 2009, 39-41 no. VI A 21, 109 no. VII A 36, 124, 187-189, with previous bibliography); G. 3 (Oța/Sîrbu 2009, 41-44 nos. VI A 22, 23, 125, 187-189, with previous bibliography); G. 6 (Oța/Sîrbu 2009, 44, 45 no. VI A 24, 109 no. VII A 38, 125, 187-189, with previous bibliography).

19. Lișcoteanca (comm. of Bordei Verde, Brăila County) Movila Olarului; G. 7 (Oța/Sîrbu 2009, 45-47 no. VI B 25, 111 no. VII C 43, 127, 185-187, with previous bibliography); G. 13 (Oța/Sîrbu 2009, 47, 48 no. VI B 26, 128, 185-187, with previous bibliography).

20. Luciu (comm. of Luciu, Buzău County) - Popina pe Balta Mică; G. (Bichir 1977, 168, 172, 177, 184, 186; 1985, 1166; Drâmbocianu 1974, 303-307; Popa 2009, 82; 2015, 171; Skóra/Niezabitowska-Wiśniewska 2018, 164 no. 17).

21. Măriuța (comm. of Belciugatele, Călărași County) - La Movilă; G. 2/2009 (Sîrbu et al. 2014, 55-57, 129, with previous bibliography).

22. Mohreanu (comm. of Ulmu, Brăila County); G. (Oța/Sîrbu 2009, 48-52 nos. VII A 28-30, 129, 187, with previous bibliography).

23. Oltenița (Călărași County) - Puțul de cărămidă; G. 1 (Sîrbu et al. 2014, 62, 63 nos. 28-34 E, 131, with previous bibliography).
24. Oltenița (Călărași County) - Renie; G. 1 (Sîrbu et al. 2014, 63, 64 nos. 28-34 F, 121, 122, with previous bibliography); G. 7 (Sîrbu et al. 2014, 66, 67, 121, 122, with previous bibliography); G. 9 (Sîrbu et al. 2014, 68, 121, 122); unknown context (Sîrbu et al. 2014, 68, nos. 1, 2, with previous bibliography).

25. Păuleasca (comm. of Frumoasa, Teleorman County); G. 57 (Sîrbu et al. 2014, 70-72, 126, with previous bibliography).

26. Râmnicelu (comm. of Râmnicelu, Brăila County) - Popină; G. 3 (Oța/Sîrbu 2009, 56-59 nos. VIII A 34, 35, 130, 185-187, with previous bibliography); G. 5 (Oța/Sîrbu 2009, 59-61 no. VIII A 36, 130, 185-187, with previous bibliography); G. 9 (Oța/Sîrbu 2009, 61 no. VIII A 37, 131, 185-187, with previous bibliography); G. 14 (Oța/Sîrbu 2009, 52-56 nos. VIII A 31-33, 131, 132, 185-187, with previous bibliography).

27. Smeeni (comm. of Smeeni, Buzău County) - Movila Mare; G. 2 (Frînculeasa et al. 2017, 54; Simache/Teodorescu 1962, 279).

28. Smeieni (comm. of Smeeni, Buzău County) - sat; G. (Bichir 1977, 171 note 30, 188; 1996, 299, 300; Harhoiu 1993, 46).

29. Spiru Haret (comm. of Berteștii de Jos, Brăila County) - Cornu Malului; G. 1 (Oța/Sîrbu 2009, 63-66 nos. IX A 39, 40, 115, 116 no. X A 53, 133, 196, with previous bibliography).

30. Sudiți (comm. of Gherăseni, Buzău County) - Movila de la Bălaia; G. (Constantinescu 1978, 24; Frînculeasa 2010, 25 note 13,29$)$.

31. Târgșoru Vechi (comm. of Târgșoru Vechi, Prahova County); G. 184 (Bichir 1972, 156, 161; 1977, 184, 186; 1985, 1171; Diaconu 1965, 20, 22, 24, 26, 28; Mirițoiu 2003, 205 no. 70); G. 198 (Bichir 1972, 161; 1977, 184, 186; Diaconu 1965, 21-26, 28); G. 200 (Bichir 1971, 277; 1972, 141, 161; 1977, 172, 186; 1985, 1168; Diaconu 1965, 19, 21, 24; Mirițoiu 2003, 205 no. 70); G. 206 (Diaconu 1965, 21); G. 228 (Diaconu 1965, 21); G. 253 (Diaconu 1965, 22, 28); G. 267 (Diaconu 1965, 22); unpublished graves (Niculescu 2003, 193-195).

32. Tichilești (comm. of Tichilești, Brăila County); G. 2 (Oțal Sîrbu 2009, 70-72 no. X A 44, 116 no. XI A 54, 134, 196, with previous bibliography); G. 4 (Oța/Sîrbu 2009, 67-70 nos. X A 42, 43, 134, 196, with previous bibliography).

33. Ulmeni (comm. of Ulmeni, Călărași County); G. 1 (Sîrbu et al. 2014, 76, 77, 127-128, with previous bibliography); G. 2 (Sîrbu et al. 2014, 77, 78, 127, 128, with previous bibliography); G. 3 (Nowakowski 1988, 114; Sîrbu et al. 2014, 78-81, 127, 128, with previous bibliography); G. 4 (Sîrbu et al. 2014, 81, 82, 127, 128, with previous bibliography); G. 5 (Sîrbu et al. 2014, 82, 127, 128, with previous bibliography); accidental discoveries (Sîrbu et al. 2014, 82, 83, nos. 1-3, with previous bibliography); unknown context (Sîrbu et al. 2014, 83, 84, no. 3, with previous bibliography).

34. Ulmu (comm. of Ulmu, Călărași County); G. 1 (Sîrbu et al. 2014, 84, nos. 42, 43 A, 131, with previous bibliography).

35. Unirea (comm. of Unirea, Călărași County); G. (Sîrbu et al. 2014, 84, 85, 132, with previous bibliography).

36. Viespești (comm. of Sprâncenata, Olt County); G. (Bichir 1996, 310; Butoi/Mincă 1979, 273; Oța/Sîrbu/Grosu 2012, 81).

37. Vitănești (comm. of Vitănești, Teleorman County); T. II, G. 2 (Sîrbu et al. 2014, 85-89, 131, with previous bibliography).

38. Vlad Țepeș (comm. of Vlad Țepeș, Călărași County); G. 2 (Sîrbu et al. 2014, 89, 90, with previous bibliography). 


\section{LITERATURE}

Barnea 1995 - A. Barnea: Cronica cercetărilor arheologice efectuate în 1994 de Institutul de Arheologie "Vasile Pârvan" din Bucureşti. Studii și Cercetări de Istorie Veche și Arheologie 46/3-4, 1995, 281-290.

Berg 2002 - R. Berg: Wearing Wealth. Mundus muliebris and Ornatus as Status Markers for Women in Imperial Rome. In: P. Setälä/R. Berg/R. Hälikkä/M. Keltanen/ J. Pölönen/V. Vuolanto (eds.): Women, Wealth and Power in the Roman Empire. Acta Instituti Romani Finlandiae 25. Rome 2002, 15-73.

Bichir 1971 - Gh. Bichir: Les Sarmates sur le territoire de la Roumanie. In: Actes du VIII Congrès International des Sciences Préhistoriques et Protohistoriques I. Beograd 9-15 septembre 1971. Rapports généraux. Beograd 1971, 275-285.

Bichir 1972 - Gh. Bichir: Sarmații la Dunărea de Jos în lumina ultimelor cercetări. Pontica 5, 1972, 137-176.

Bichir 1977 - Gh. Bichir: Les Sarmates au Bas-Danube. Dacia. Nouvelle Série 21, 1977, 167-197.

Bichir 1985 - Gh. Bichir: Sarmații şi relațiile lor cu getodacii (II). Revista de Istorie 38, 1985, 12, 1164-1177.

Bichir 1996 - Gh. Bichir: Date noi cu privire la pătrunderea sarmaților în teritoriul geto-dacic (II). Studii și Cercetări de Istorie Veche și Arheologie 47/3, 1996, 297-312.

Bogdan-Cătăniciu 1983 - I. Bogdan-Cătăniciu: Die KlientelBevölkerung in Muntenien (1.-3. Jh. u. Z.). Acta Musei Napocensis 20, 1983, 67-84.

Bogdan-Cătăniciu 1997 - I. Bogdan-Cătăniciu: Muntenia în sistemul defensiv al Imperiului Roman sec. I-III p. Chr. Alexandria 1997.

Brather 2008 - S. Brather: Acculturation and Ethnogenesis along the Frontier: Rome and the Ancient Germans in an Archaeological Perspective. In: S. Brather (ed.): Archaeology and Identity. Central and East Central Europe in the Earlier Middle Ages. București 2008, 209-240.

Butoi/Mincă 1979 - M. Butoi/A. Mincă: Descoperiri sarmatice în sud-vestul Munteniei, între limesul alutan şi limesul transalutan. Materiale și Cercetări Arheologice 13, 1979, 273, 274.

Ciupercă/Măgureanu/Anton 2015 - B. Ciupercă/A. Măgureanu/A. Anton: The Presence of Rome in Barbaricum: Archaeological Evidence of the Interaction between Romans and Barbarians in the Târgșoru Vechi Area. In: L. Vagalinski/N. Sharankov (eds.): Limes XXII. Proceedings of the $22^{\text {nd }}$ International Congress of Roman Frontier Studies Ruse, Bulgaria, September 2012. Sofia 2015, 771-780.

Cociș 2004 -S. Cociș: Fibulele din Dacia romană. The Brooches from Roman Dacia. Bibliotheca Ephemeris Napocensis 3. Cluj-Napoca 2004.

Cociș/Bârcă 2014 - S. Cociș/V. Bârcă: The "Sarmatian" brooches (headknob and full catchplate variant, Almgren group VII, series I) in the Dacia province and the Barbarian environment of the Tisza River Basin. Dacia. Nouvelle Série 58, 2014, 189-214.

Constantinescu 1978 - M. Constantinescu: Un mormânt din perioada migrațiilor, descoperit la Balta Albă, județul Buzău. Mousaios 2, 1978, 22-25.

CCA Campania 1994 - Cronica cercetărilor arheologice din România. Campania 1994. Cluj-Napoca 1995.
CCA Campania 2001 - Cronica cercetărilor arheologice. Campania 2001. Bucureşti 2001.

Dan 2017 - A. Dan: The Sarmatians: Some Thoughts on the Historiographical Invention of a West Iranian Migration. In: F. Wiedermann/K. P. Hofmann/H.-J. Gehrke (Hrsg.): Vom Wandern der Völker. Migrationserzählungen in den Altertumswissenschaften. Berlin Studies of the Ancient World. Berlin 2017, 97-134.

Diaconu 1963 - Gh. Diaconu: Despre sarmați la Dunărea de Jos în lumina descoperirilor de la Tîrgşor. Studii și Cercetări de Istorie Veche și Arheologie 14/2, 1963, 323-343.

Diaconu 1965 - Gh. Diaconu: Tîrgșor - Necropola din secolele III-IV e.n. Biblioteca de Arheologie 8. București 1965.

Dragomir 1957 - I. T. Dragomir: Vestigii arheologice pe valea Călmățuiului. Materiale și Cercetări Arheologice 3, 1957, 300-310.

Dragomir 1959 - I. T. Dragomir: Raport asupra săpăturilor întreprinse la Largu (r. Filimon Sîrbu, reg. Galaţi). Materiale și Cercetări Arheologice 5, 1959, 475-482.

Dragomir/Croitoru 2011 - I. T. Dragomir/C. Croitoru: La nécropole sarmatique de Largu (dép. de Buzău). Istros 17, 2011, 31-54.

Drâmbocianu 1974 - V. Drâmbocianu: Un mormânt sarmatic descoperit la Luciu (jud. Buzău). Studii și Cercetări de Istorie Veche și Arheologie 25/2, 1974, 303-307.

Drâmbocianu 1981 - V. Drâmbocianu: Şantierul arheologic de salvare din punctul Buzău-sud. Mousaios 3, 1981, $50-57$.

Ferrary 2007 -J. L. Ferrary: L'essor de la puissance romaine dans la zone pontique. In: A. Bresson/A. Ivantchik/ J. L. Ferrary (eds.): Une koinè pontique. Cités grecques, sociétés indigènes et empires mondiaux sur le littoral nord de la Mer Noire (VII s. a.C.-III s. p.C.). Mémoires 18. Bordeaux 2007, 319-324.

Février 1987 - P. A. Février: Discussions to J. ChausserieLapree, N. Nin: La nécropole à incineration d'époque augusteénne de la Gatasse, Commune de Martigues (Bouches du Rhône). In: J. Lasfargues (ed.): Nécropoles à incinération du Haut-Empire. Table Ronde de Lyon 30 \& 31 mai 1986. Rapports Archéologiques Préliminaires de la Région Rhône-Alpes 4. Lyon 1987, 80, 81.

Fless/Treister 2007 - F. Fless/M. Treister: Der polychrome Stil der Schmuckproduction. Zu Typologie und Entwicklung einer Schmuckform im nördlichen Schwarzmeergebiet vom 1. Jh. a.C. bis ins frühe 2. Jh. p.C. In: A. Bresson/A. Ivantchik/J.-L. Ferrary (ed.): Une koinè pontique. Cités grecques, sociétés indigènes et empires mondiaux sur le littoral nord de la Mer Noire (VII ${ }^{e}$ s. a. C. $-I I I^{e}$ s. p. C.). Mémoires 18. Bordeaux 2007, 165-187.

Forest 1998 - J. D. Forest: Pratiques funéraires et jeux symboliques. In: S. Marchegay/M.-T. Le Dinahet/J.-F. Salles (eds.): Nécropoles et pouvoir. Idéologie, pratiques et interpretations. Actes du colloque Théories de la nécropole antique, Lyon, 21-25 janvier 1995. Travaux de la Maison de l'Orient méditerranéen 27. Lyon Paris - Athènes, 167-190.

Frînculeasa 2010 - A. Frînculeasa: Noi informații privind cercetările arheologice de la Sudiți, com. Gherăseni 
(jud. Buzău) - descoperiri din epoca neo-eneolitică. Mousaios 15, 2010, 23-54.

Frînculeasa et al. 2017 - A. Frînculeasa/A. Simalcsik/B. Preda/D. Garvăn: Smeeni - Movila Mare. Monografia unui sit arheologic regăsit. Târgoviște 2017.

Gabler 1976 - D. Gabler: Zu Fragen der Handelsbeziehungen zwischen den Römern und den „Barbaren“ im Gebiet östlich von Pannonien. In: H. Grünert (Hrsg.): Römer und Germanen im Mitteleuropa. Berlin 1976, 87-121.

Grane 2007 - T. Grane: Southern Scandinavian Foederati and Auxiliarii? In: T. Grane (ed.): Beyond the Roman Frontier. Roman Influences on the Northern Barbaricum. Analecta Romana Instituti Danici. Supplementum 39. Rome 2007, 83-104.

Glodariu 1984 - I. Glodariu: "Brățările” cu nodozități Latène târzii din Dacia. Acta Musei Napocensis 21, 1984, 63-80.

Harhoiu 1993 - R. Harhoiu: “Tezaurul” de la Buzău - 1941. Studii și Cercetări de Istorie Veche și Arheologie 44/1, 1993, 41-51.

Hauser 2006 - S. R. Hauser: Zur Einleitung: Archäologische Annäherungen an Nomaden. In: S. R. Hauser (Hrsg.): Die Sichtbarkeit von Nomaden und Saisonaler Besiedlung in der Archäologie. Multidisziplinäre Annäherungen an ein methodisches Problem. Mitteilungen des SFB 9. Orientwissenschaftliche Hefte 21. Halle/ Salle 2006, 1-26.

Härke 1994 - H. Härke: Data types in burial analysis. In: B. Stjernquist (ed.): Prehistoric Graves as a Source of Information. Symposium at Kastlösa, Öland, May 21-23, 1992. Konferenser 29. Stockholm 1994, 31-39.

Hellström 2018 - K. Hellström: Fibeln und Fibeltracht der Sarmatischen Zeit im Nordschwarzmeergebiet (2. Jh. v. Chr. 3. Jh. n. Chr.). Archäologie im Eurasien 39. Bonn 2018.

Honeychurch/Makarewicz 2016 - W. Honeychurch/C. A. Makarewicz: The Archaeology of Pastoral Nomadism. Annual Review of Anthropology 45, 2016, 341-359.

Hrnčiarik/Kuzmová 2016 - E. Hrnčiarik/K. Kuzmová: Evidence of trade and exchange during the Roman period in Barbaricum (territory of Slovakia). In: A. Rubel (Hrsg.): Inklusion, Exklusion und Identität im Römischen Reich und im Barbaricum (1.-3. Jahrhundert n. Chr.). Konstanz 2016, 149-162.

Istvánovits/Kulcsár 2003 - E. Istvánovits/V. Kulcsár: Some traces of Sarmatian-Germanic contacts in the Great Hungarian Plain. In: C. von Carnap-Bornheim (Hrsg.): Kontakt-Kooperation-Konflikt. Germanen und Sarmaten zwischen dem 1. und dem 4. Jahrhundert nach Christus. Internationales Kolloquium des Vorgeschichtlichen Seminars der Philipps-Universität Marburg, 12.-16. Februar 1998. Neumünster 2003, 227-238.

Istvánovits/Kulcsár 2013 - E. Istvánovits/V. Kulcsár: The "upper class" of Sarmatian society in the Carpathian basin. In: M. Hardt/ O. Heinrich-Tamáska (Hrsg.): Macht des Goldes, Gold der Macht. Herrschafts- und Jenseitsrepräsentation zwischen Antike und Frühmittelalter im mittleren Donauraum. Akten des 23. Internationalen Symposiums der Grundprobleme der Frühgeschichtliche Entwicklung im mittleren Donauraum, Tengelic, 16.-19. 11. 2011. Forschungen zu Spätantike und Mittelalter 2. Weinstadt 2013, 195-209.
Istvánovits/Kulcsár 2017 - E. Istvánovits/V. Kulcsár: Sarmatians - History and Archaeology of a Forgotten People. Monographien des Römisch-Germanischen Zentralmuseums 123. Mainz 2017.

Jílek 2015 - J. Jílek: Roman Metall Vessels in the Milieu of Germanic Elites in the Middle Danube Region. Studia Hercynica 19/1-2, 2015, 169-188.

Khazanov 1981 - A. M. Khazanov: Myths and Paradoxes of Nomadism. European Journal of Sociology 22/1, 1981, 141-153.

Khazanov 2019 - A. M. Khazanov: Steppe Nomads in the Eurasian Trade. Chungara. Revista de Antropología Chilena 51/1, 2019, 85-93.

Kradin 2000-N. N. Kradin: Nomadic Empires in Evolutionary Perspective. In: N. Kradin/A. Korotayev/D. Bondarenko (eds.): Alternatives of Social Evolution. Vladivostok 2000, 425-449.

Kradin 2002 - N. N. Kradin: Nomadism, Evolution and World-Systems: Pastoral Societies in Theories of Historical Development. Journal of World-System Research 8/3, 2002, 368-388.

Kradin 2014 - N. N. Kradin: Nomads of Inner Asia in transition. Moscow 2014.

Kradin 2015 - N. N. Kradin: The Ecology of Inner Asian Pastoral Nomadism. In: P. N. Kardulias (ed.): The Ecology of Pastoralism. Boulder 2015, 41-70.

Kraskovská 1981 - L'. Kraskovská: Römische Glasgefässe in der Slowakei. Slovenská archeológia 29, 1981, 377-392.

Krekovič 1987 - E. Krekovič: Rímske importy na Slovensku. Památky archeologické 78, 1987, 231-282.

Krekovič 2000 - E. Krekovič: Roman Pottery beyond the frontier: the Middle Danubian region. Rei Cretariae Romanae Fautorum Acta 36, 2000, 259-262.

Krekovič 2011 - E. Krekovič: Romans and Barbarians: Some Remarks on Cultural Contact, Influence and Material Culture. In: E. C. De Sena/H. Dobrzanska (eds.): The Roman Empire and Beyond: Archaeological and Historical Research on the Romans and Native Cultures in Central Europe. British Archaeological Reports International Series 2236. Oxford 2011, 81-83.

Laser/von Schnurbein 1994-R. Laser/S. von Schnurbein: Einführung in das Vorhaben „Corpus der römischen Funde im europäischen Barbaricum“. In: Laser/Voß 1994, 1-4.

Laser/Voß 1994 - R. Laser/H.-U. Voß (Hrsg.): Corpus der römischen Funde im europäischen Barbaricum. Deutschland. Band 1. Bundesländer Brandenburg und Berlin. Bonn 1994.

Lazăr/Ștefan/Vasile 2013 - C. Lazăr/C. E. Ștefan/G. Vasile: Considerații privind resturile osteologice umane din cadrul unor așezări eneolitice din sud-estul României. Studii de Preistorie 10, 2013, 67-88.

Leahu/Trohani 1979 - V. Leahu/G. Trohani: Săpăturile arheologice de la Vităneşti, jud. Teleorman. Cercetări Arheologice 3, 1979, 127-141.

Lind 1991 - L. Lind: Rome Outside the Empire in Northern and Eastern Europe. In: A.-M. Leander Touati/ E. Rystedt/Ö. Wikander (eds.): Munuscula Romana. Papers read at a conference in Lund (October 1-2. 1988 ) in celebration of the re-opening of the Swedish Institute in Rome. Stockholm 1991, 133-138.

Lund-Hansen 1987 - U. Lund-Hansen: Römischer Import im Norden. Warenaustausch zwischen dem römischer Reich 
und dem freien Germanien während der Kaiserzeit unter besonderer Berücksichtigung Nordeuropas. Nordiske Fortidsminder serie B, Band 10. København 1987.

Meyer 2013 - M. Meyer: Romanisierung? Überlegugen zum römischen Einfluss auf die kaiserzeitliche Germania Magna. In: A. Rubel (Hrsg.): Imperium und Romanisierung. Neue Forschungsansätze aus Ost und West zu Ausübung, Transformation und Akzeptanz von Herrschaft im Römischen Reich. SAGA Studien zu Archäologie und Geschichte des Altertums I. Konstanz 2013, 57-72.

Mirițoiu 2003 - N. Mirițoiu: Sarmatische Gräber mit künstlich deformierten Schädeln in Muntenien. In: C. von Carnap-Bornheim (Hrsg.): Kontakt-KooperationKonflikt. Germanen und Sarmaten zwischen dem 1. und dem 4. Jahrhundert nach Christus. Internationales Kolloquium des Vorgeschichtlichen Seminars der Philipps-Universität Marburg, 12.-16. Februar 1998. Neumünster 2003, 204, 205.

Mordvintseva 2013 - V. Mordvintseva: The Sarmatians: The Creation of Archaeological Evidence. Oxford Journal of Archaeology 32, 2013, 213-219.

Mordvintseva 2016 - V. Mordvintseva: Barbarians of the North-Pontic Region and Their Contacts with Centres of the Antique Civilization from the $3^{\text {rd }}$ Century BCE to the Mid $3^{\text {rd }}$ Century CE (According to the Research of the Elite Barrows). In: V. Cojocaru/A. Rubel (eds.): Mobility in Research of the Black Sea Region. Pontica et Mediterranea. Band 6. Cluj-Napoca 2016, 387-438.

Morintz 1960 - S. Morintz: Ein sarmatisches Grab aus Căscioarele. Dacia. Nouvelle Série 4, 1960, 553-560.

Morintz/Ionescu 1968 - S. Morintz/B. Ionescu: Cercetări arheologice în împrejurimile oraşului Oltenița (1958-1967). Studii și Cercetări de Istorie Veche 19/1, 1968, 95-128.

Morintz/Ionescu 1970 - S. Morintz/B. Ionescu: Mormintele sarmatice din sud-estul județului Ilfov. In: R. Florescu/A. Pavel (red.): Sesiunea de Comunicări a Muzeelor de Istorie 1964. Volume II. Biblioteca Muzeelor VII. București 1970, 37-54.

Niculescu 2003 - Gh. A. Niculescu: Die sarmatische Kultur im Zusammenhang der kaiserzeitlichen archäologischen Funde aus Muntenien - unter besonderer Berücksichtigung der Funde von Tîrgşor. In: C. von Carnap-Bornheim (Hrsg.): Kontakt-KooperationKonflikt. Germanen und Sarmaten zwischen dem 1. und dem 4. Jahrhundert nach Christus. Internationales Kolloquium des Vorgeschichtlichen Seminars der Philipps-Universität Marburg, 12.-16. Februar 1998. Neumünster 2003, 177-205.

Nowakowski 1988 - W. Nowakowski: Metallglocken aus der römischen Kaiserzeit im europäischen Barbaricum. Archeologia Polona 27, 1988, 69-146.

Olbrycht 2000 - M. J. Olbrycht: Notes on the presence of Iranian peoples in Europe and their Asiatic relations. In: J. Pstrusińska/A. Fear (eds.): Collectanea CeltoAsiatica Cracoviensia. Kraków 2000, 101-140.

Oța 1999 - L. Oța: Relations between the Roman Empire and Sarmatians on the Lower Danubian limes. In: N. Gudea (ed.): Proceedings of the XVII International Congress of Roman Frontier Studies. Zalău 1999, 885-894.
Oța 2007 - L. Oța: Sarmații din Muntenia şi Imperiul roman. Analele Banatului. Serie Nouă 15. Arheologie Istorie, 2007, 51-55.

Oța 2014-2015 - L. Oța: Observations on the Sarmatian Graves in Wallachia in which Hand-made Pottery Was Deposited. Thraco-Dacica. Serie nouă 6-7 (29-30), 2014-2015, 95-118.

Oța 2015a - L. Oța: Câteva observații cu privire la importurile romane din mormintele sarmatice din Muntenia. Acta Terrae Fogarasiensis 4, 2015, 25-33.

Oța 2015b - L. Oța: Despre mormintele aparținând unor indivizi cu cranii deformate la sarmații din Muntenia și Moldova. In: B. Ciupercă (ed.): Arheologia mileniului I p. Chr. IV. Nomazi și autohtoni în mileniul I p. Chr. In memoriam Maria Comșa. Brăila 2015, 119-144.

Oța 2016 - L. Oța: Beyond the Lower Danubian Limes Sarmatians and Romans. In: C. G. Alexandrescu (ed.): Troesmis - A Changing Landscape. Romans and the Others in the Lower Danube Region in the First Century BC-Third Century AD. Proceedings of an International Colloquium Tulcea $\left(7^{\text {th }}-10^{\text {th }}\right.$ of October 2015). Cluj-Napoca 2016, 129-150.

Oța 2018 - L. Oța: Sarmatian Children Graves in Wallachia and Moldavia. Tyragetia. Serie nouă 12, 2018, 41-70.

Oța 2020 - L. Oța: Câteva observații despre descoperirile arheologice din secolul al III-lea p. Chr. în Muntenia. In: I. Cândea (ed.): Tracii și vecinii lor în antichitate: arheologie și istorie/The Thracians and Their Neighbours in Antiquity: Archaeology and History. Studies in Honor of Valeriu Sîrbu at his $70^{\text {th }}$ Anniversary. Brăila 2020, 417-442.

Oța/Georgescu/Baltă 2015 - L. Oța/M. Georgescu/Z. I. Baltă: Despre cele două morminte din tell-ul de la Dridu. Materiale și Cercetări Arheologice. Serie Nouă 11, 2015, 143-156.

Oța/Oța 2015 - L. Oța/S. Oța: “Tezaurul de la Buzău”/“The treasure of Buzău". Istros 21, 2015, 537-576.

Oța/Sîrbu 2009 - L. Oța/V. Sîrbu: Sarmaţii din județul Brăila. Brăila 2009.

Oța/Sîrbu 2010 - L. Oța/V. Sîrbu: A Few Observations on the Arrival of the Sarmatians in the Wallachia Plain. Eirene. Studia Graeca et Latina 46/1-2, 2010, 191-201.

Oța/Sîrbu 2012 - L. Oța/V. Sîrbu: La céramique dacique dans les tombes sarmatiques de Valachie. Istros 18, 2012, 125-163.

Oța/Sîrbu 2013 - L. Oța/V. Sîrbu: The Bărăgan in the $1^{\text {st }}-3^{\text {rd }}$ Centuries AD: Dacians, Romans, Sarmatians. In: V. Sîrbu/R. Ştefănescu (eds.): "Necropolises, Cult places, Religion, Mythology" - The Thracians and their Neighbors in the Bronze and Iron Ages. Proceedings of the $12^{\text {th }}$ International Congress of Thracology, Târgovişte, $10^{\text {th }}-14^{\text {th }}$ September 2013. Volume II. Braşov 2013, 289-309.

Oța/Sîrbu 2016a - L. Oța/V. Sîrbu. The early settlement of Sarmatians in Wallachia. Tyragetia. Serie nouă 10/1, 2016, 261-284.

Oța/Sîrbu 2016b - L. Oța/V. Sîrbu: Aproape de limes Sarmații din Muntenia, Moldova, Crișana și Banat. In: V. Sîrbu (ed.): Interdisciplinary Methods of Research for Prehistoric and Protohistoric Funerary Monuments. Proceedings of the $15^{\text {th }}$ International Colloquium of 
Funerary Archaeology, Brăila, 20 $20^{\text {th }}-22^{\text {nd }}$ May 2016. Istros 22. Brăila 2016, 205-255.

Oța/Sîrbu 2019a - L. Oța/V. Sîrbu: Only by Chance? Sarmatians, Romans, Dacians in Wallachia and Moldavia. In: V. Sîrbu/C. Schuster/D. Hortopan (eds.): Border Guards of the Passes, from the Fortresses and the Graves. The Bronze and Iron Ages. Proceedings of the $17^{\text {th }}$ International Colloquium of Funerary Archaeology, Târgu Jiu, Gorj County (Romania), $4^{\text {th }}-7^{\text {th }}$ October 2018. Târgu Jiu - Brăila 2019, 149-174.

Oța/Sîrbu 2019b, in press - L. Oța/V. Sîrbu: Funerals and Social Status at the Sarmatians from a Border Area: Wallachia and Moldavia. In: S. Matei (ed.): Bronze and Iron Age in Eurasia: Rituals and Grave Goods as Possible Markers of the Social Identity of the Dead. Proceedings of the $18^{\text {th }}$ International Colloquium on Funerary Archaeology, Buzău, $17^{\text {th }}-20^{\text {th }}$ October 2019. Mousaios 23. Buzău 2019, in press.

Oța/Sîrbu/Grosu 2012 - L. Oța/V. Sîrbu/A. Grosu: Morminte sarmatice pe teritoriul județului Olt. Muzeul Oltului 2, 2012, 79-92.

Oța/Sîrbu/Matei 2013 - L. Oța/V. Sîrbu/S. Matei: "Male" and "female" grave-goods in Sarmatian tombs found in Wallachia. In: V. Sîrbu/S. Matei (eds.): Bronze and Iron Age Graves from Eurasia - Gender between Archaeology and Anthropology. Proceedings of the $13^{\text {th }}$ International Colloquium of Funerary Archaeology, Buzău-Romania, $17^{\text {th }}-21^{\text {st }}$ October 2012. Mousaios 18. Buzău 2013, 325-352.

Párducz 1941 - M. Párducz: Az Örvényi Jazig lelet. Folia Archaeologica 3-4, 1941, 159-163.

Parker-Pearson 1999 - M. Parker-Pearson: The Archaeology of Death and Burial. Stroud 1999.

Pearce 2000 - J. Pearce: Burial, society and context in the provincial Roman world. In: J. Pearce/M. Millet/ M. Struck (eds.): Burial, Society and Context in the Roman World. Oxford 2000, 1-12.

Petolescu 2000 - C. C. Petolescu: Dacia şi Imperiul Roman. Bucureşti 2000.

Pitts 1989 - L. F. Pitts: Relations between Rome and the German "Kings" on the Middle Danube in the First to Fourth Centuries A.D. Journal of Roman Studies 79, 1989, 45-58.

Popa 2007 - Al. Popa: Flabella im Barbaricum? Überlegungen zu einer Fundgruppe bronzener Gegenstände aus dem Gebiet Jenseits der Provinzen Dacia und Moesia Inferior. Germania 85, 2007, 329-347.

Popa 2009 - Al. Popa: Consemnări asupra mormântului de la Tălmaza şi a inventarului lui. Notă despre răspândirea evantaielor romane în barbaricum-ul European. Ephemeris Napocensis 19, 2009, 79-108.

Popa 2011 - Al. Popa: "Importuri" provincial-romane și romanizare în hinterlandul provinciilor romane Dacia și Moesia Inferior. In: Al. Rubel (coord.): Romanizarea: impunere și adeziune în Imperiul Roman. Iași 2011, 201-221.

Popa 2013 - Al. Popa: Provinzial-römische Importfunde als Anzeichen der Romanisierung jenseits der römischen Reichgrenze? Fallbeispiel KarpatenDnestr-Raum. In: Al. Rubel (Hrsg.): Imperium und Romanisierung. Neue Forschungsansätze aus Ost und West zu Ausübung, Transformation und Akzeptanz von
Herrschaft im Römischen Reich. SAGA Studien zu Archäologie und Geschichte des Altertums I. Konstanz 2013, 127-144.

Popa 2015 - Al. Popa: Untersuchungen zu den römischbarbarischen Kontakten östlich der römische Provinz Dacia. Antiquitas 3. Abhandlungen zur Vor- und Frühgeschichte, zur klassischen und provinzial-römischen Archäologie und zur Geschichte des Altertums 47. Bonn 2015.

Przybyła/Rydzewska 2019 - M. J. Przybyła/E. Rydzewska: Amber as passage money on the journey to the afterlife: the role of the Jutland amber in the Late Roman and Early Migration periods (ca. 160-450 AD). In: R. Annaert (ed.): Early medieval waterscapes. Risks and opportunities for (im)material cultural exchange. Neue Studien zur Sachsenforschung 8. Braunschweig 2019, 153-172.

Rența 2000 - E. Rența: Necropola sarmatică de la Bucu, județul Ialomița. Ialomiţa 3, 2000, 39-57.

Rența 2016 - E. Rența: Cercetările arheologice de salvare de la Ciulnița, județul Ialomița (1994-1997). Seria Situri Arheologice 5. Târgoviște 2016.

Rogers 2007 - J. D. Rogers: The Contingencies of State Formation in Eastern Inner Asia. Asian Perspectives 46/2, 2007, 249-274.

Rosetti 1934 - D. V. Rosetti: Siedlungen der Kaiserzeit und der Völkerwanderungszeit bei Bukarest. Germania 18/3, 1934, 208-209.

Roymans 2007 - N. Roymans: Understanding social change in the Late Iron Age Lower Rhine region. In: C. Haselgrove/T. Moore (eds.): The Later Iron Age in Britain and Beyond. Oxford 2007, 478-491.

Rustoiu 1997 - A. Rustoiu: Fibulele din Dacia preromană (sec. II î.e.n. - I e.n.). Bibliotheca Thracologica 22. București 1997.

Scheid 2008 - J. Scheid: En guise de prologue: de l'utilisation correcte des sources écrites dans l'étude des rites funéraires. In: J. Scheid (ed.): Pour une archéologie du rite: nouvelles perspectives de l'archéologie funéraire. Rome 2008.

Schlott/Spennemann/Weber 1985 - C. Schlott/D. R. Spennemann/G. Weber: Ein Verbrennungsplatz und Bestattungen am spätlatènezeitlichen Heidetränk-Oppidum im Taunus. Germania 63/2, 1985, 439-505.

Simache/Teodorescu 1962 - N. Simache/V. Teodorescu: Săpăturile arheologice de salvare de la Smeieni (r. Buzău, reg. Ploieşti). Materiale și Cercetări Arheologice 8, 1962, 273-281.

Simonenko 2011 - A. V. Simonenko: Rimskij import u sarmatov Severnogo Pričernomorija. Sankt-Peterburg 2011.

Simonenko 2013 - A. V. Simonenko: Rimskija i provincial'nija import u Sarmatov Severnogo Pričernomorija. Tipologija $i$ hronologija. Saarbrücken 2013.

Simonenko/Marčenko/Limberis 2008 - A. Simonenko/ I. I. Marčenko/N. Ju. Limberis: Römische Importe in sarmatischen und maiotischen Gräbern. Archäologie in Eurasien 25. Mainz 2008.

Situri 1983-1992 - Situri arheologice cercetate în perioada 1983-1992. Brăila 1996.

Skóra/Niezabitowska-Wiśniewska 2018 - K. Skóra/B. Niezabitowska-Wiśniewska: Flabellum czy calamistrum? 
I jeszcze jeden, niezwykle intrygujący zabytek... z Dratowa. In: B. Niezabitowska-Wiśniewska/ P. Łuczkiewicz/S. Sadowski/M. Stasiak-Cyran/M. Erdrich (eds.): Studia Barbarica II. For Professor Andrzej Kokowski on his $75^{\text {th }}$ Birthday. Lublin 2018, 130-180.

Sîrbu et al. 2014 - V. Sîrbu/L. Oța/A. Vîlcu/M. Neagu/ V. Oprea: Sudul Munteniei în sec. I a. Chr.-III p. Chr. Sarmați, daci,romani. Brăila 2014.

Suceveanu 2000 - Al. Suceveanu: Histria. X. La céramique romaine des $I^{e r}-I I I^{e}$ siècles ap. J.-C. Bucureşti 2000.

Ștefan/Dumitrașcu/Mărgărit 2012 - C. E. Ștefan/V. Dumitrașcu/M. Mărgărit: Restitutiones Archaeologicae: așezarea de tip tell de la Coșereni 'Măgura de la Comana', jud. Ialomița. Buletinul Muzeului Județean Teleorman. Seria Arheologie 4, 2012, 71-100.

Tempelmann-Maczyńska 1985 - M. TempelmannMączyńska: Die Perlen der römischen Kaiserzeit und der frühen Phase der Völkerwanderungszeit im mitteleuropäischen Barbaricum. Römisch-Germanische Forschungen 43. Mainz am Rhein 1985.

Tuffreau-Libre 2000 - M. Tuffreau-Libre: Pottery assemblages in Gallo-Roman cemeteries. In: J. Pearce/M. Millet/M. Struck (eds.): Burial, Society and Context in the Roman World. Oxford 2000, 52-60.

Ursulescu/Kogălniceanu 2002-2004 - N. Ursulescu/R. Kogălniceanu: Necropola sarmatică de la Isaiia (c.
Răducăneni, j. Iași). Date preliminare. Cercetări Istorice. Serie Nouă 21-23, 2002-2004, 27-58.

Vaday 1982-1983 - A. H. Vaday: Das Gräberfeld der Jazyges Metanastae in Mezőcsát-Hörcsögös. Mitteilungen des Archäologischen Instituts der Ungarischen Akademie der Wissenschaften 12-13, 1982-1983, 167-187.

Vaday 1988-1989 - A. H. Vaday: Die sarmatischen Denkmäler des Komitats Szolnok. Ein Beitrag zur Archäologie und Geschichte des sarmatischen Barbaricums. Antaeus 17-18. Budapest 1988-1989.

Vaday 2005 - A. Vaday: Corpus der römische Funde im europäischen Barbaricum. Ungarn. Band 1. Komitat Szolnok. Budapest 2005

Vaday/Istvánovits/Kulcsár 1989 - A. H. Vaday/E. Istvánovits/V. Kulcsár: Sarmatian Costume in the Carpathian Basin. Klio 71, 1989, 107-114.

Wendrich/Barnard 2008 - W. Wendrich/H. Barnard: The archaeology of mobility: definitions and research approaches. In: H. Barnard/W. Wendrich (eds.): The archaeology of mobility. Old world and new world nomadism. Los Angeles 2008, 1-21.

Žuravlev 2014 - D. Žuravlev: "Braslety" i kol'ca s vystupami iz pozdneskifskih i sarmatskih pamjatnikov Severnogo Pričernomorija. Problemyi istorii, filologii, kultury. Journal of Historical, Philological and Cultural Studies 43, 2014, 59-85.
Manuscript accepted 28. 9. 2020

Translated by Alexandra Decu
Dr. Liana Oța

“Vasile Pârvan" Institute of Archaeology

Henri Coandă str. 11

RO - 010667 Bucharest

loredanaota@yahoo.com

\title{
Sarmatské hroby s rímskymi importmi z Valašska
}

\author{
$\mathrm{Li}$ a n a $\mathrm{Otca}$
}

\section{SÚHRN}

Príchod sarmatských spoločenstiev do Valašska (oblasti medzi Dunajom a Karpatmi, ohraničenej na západe riekou Olt) a Moldavska (názov, ktorý v tejto štúdii označuje územie medzi riekou Prut a Karpatmi) je archeologicky potvrdený od konca 1. stor. n. 1. Sarmatské nálezy v spomínaných regiónoch pozostávajú takmer výlučne z hrobov. Je len málo výnimiek, ktoré reprezentujú náhodné nálezy alebo nálezy zo systematických výskumov, ktoré však mali iné ciele. $Z$ celkového počtu okolo 270 sarmatských hrobov vo Valašsku boli rímske importy objavené v $71 \mathrm{z}$ nich. Cielom tejto diskusie nie je ani tak typologická analýza rímskych predmetov, ako skôr charakteristika rituálneho a hrobového inventára hrobov, v ktorých boli takéto predmety uložené.

\section{Pohrebný rítus a rituál sarmatských hrobov z Valašska, ktoré obsahovali rímske hrobové predmety}

Rímske predmety sa našli v 14 izolovaných hroboch a v 55 hroboch 22 hrobových skupín. Väčšina hrobov s rímskymi predmetmi je plochá (43), 14 hrobov je usporiadaných $\mathrm{v}$ telloch a sedem hrobov bolo objavených 
v pieskových dunách. Počet mohylových hrobov je nízky - len šest'. Zvyčajne bol do hrobu uložený len jeden mŕtvy jedinec. V jednom hrobe boli výnimočne uložení dvaja zosnulí - muž a žena. Prevláda orientácia hrobov v smere S - J. Väčšina mŕtvych bola uložená na chrbte, s vystretými rukami a nohami. Rímske predmety boli uložené skôr v hroboch dospelých jedincov (32 prípadov) než detí (13 prípadov).

\section{Rímska hrobová výbava}

Typológia rímskych predmetov nájdených $\mathrm{v}$ hroboch a náhodných nálezov pripisovaných Sarmatom vo Valašsku nie je vel'mi rôznorodá: keramické nádoby (29 nádob nájdených v 22 hroboch), bronzová rajnica, sklenené nádoby (dve), koráliky (ako ozdoby v 33 hroboch alebo zdobiace odev v 11 hroboch), ozdobné predmety (bronzová náušnica, zlatý prívesok a pät bronzových zvoncov), spony (tri s istým rímskym pôvodom), vejáre (dva) a opakovane použitý uzáver na truhlicu. Zvyčajne bol v sarmatských hroboch z Valašska nájdený len jeden rímsky predmet.

\section{Hrobová výbava}

Najbežnejší inventár uložený v 71 hroboch z Valašska, v ktorých sa našli rímske predmety, predstavujú keramické nádoby nájdené zo 43 hrobov. Ďalšie kategórie hrobovej výbavy zoradené zostupne podla početnosti sú: ozdoby (40 hrobov), odevné doplnky ( 21 hrobov), toaletné potreby, najmä zrkadlá (16 hrobov), nástroje z domácnosti (11 hrobov), zbrane (5 hrobov), doplnené výnimočne o lastúry, kriedu, uhlíky, kĺbovú kost’ a sklenenú nádobu.

\section{Datovanie rímskych výrobkov}

Na základe datovania rímskych predmetov chronológia sarmatských hrobov ukázala, že hroby možno datovat' do troch fáz, ktoré reprezentujú mnohé momenty usídlovania týchto spoločenstiev vo Valašsku:

1. druhá polovica 1. stor. n. l. a prvá polovica 2. stor. n. 1 . (neskorá fáza B2a a skorá fáza B2b);

2. druhá polovica 2. stor. n. 1. a prvá polovica 3. stor. n. 1 . (C1 a začiatok fázy C2);

3. druhá polovica 3. stor. n. 1. (neskorá fáza C2).

15 hrobov možno datovat’ do prvej fázy príchodu Sarmatov do Valašska. Väčšina hrobov s rímskymi predmetmi (49) je chronologicky ohraničená v druhej fáze sarmatského osídlenia Valašska. Štyri prípady patria k najmladším sarmatským hrobom vo Valašsku. Vzhladom na to, že v hroboch sa nenašli predmety rímskeho pôvodu, možno ich datovat' bud' na koniec 1 . stor. n. 1. a začiatok nasledujúceho storočia, alebo do druhej polovice 2. stor. až 3. stor. n. 1 .

\section{Zaobstarávanie rímskych predmetov}

Typológia rímskych výrobkov pozostáva len z keramiky, ozdôb alebo odevných doplnkov a výnimočne zo sklenených alebo bronzových nádob, uzáveru na truhlicu, prípadne vejárov. Ich obmedzená typologická variabilita, $\mathrm{v}$ kombinácii s absenciou skutočne cenných predmetov (kovových nádob, ozdôb zo vzácnych kovov) indikujú spôsob, akým sa tieto výrobky dostali do sarmatského prostredia vo Valašsku. Najpravdepodobnejším vysvetlením je obchod, ked’̌̌e nateraz neexistujú argumenty podporujúce iné možné vysvetlenia, ako napríklad lúpež, výplata alebo diplomatické dary. Obchodné aktivity patria prevažne k tzv. "cezhraničnému obchodu“, odohrávajúcemu sa zvyčajne v oblasti rímskych pevností, kde boli v obehu bežné nádoby a iné malé predmety. Menej často sa viažu k dial'kovému obchodu, kvôli nízkej hodnote tovaru.

\section{Úloha rímskych predmetov v sarmatských hroboch z Valašska}

Z diskusie o charakteristike sarmatských hrobov s rímskou hrobovou výbavou vyplýva, že analyzované hroby nemajú konkrétne znaky týkajúce sa usporiadania hrobu, pohrebného rituálu alebo úpravy uložia inventára $\mathrm{v}$ porovnaní so zvyškom hrobov, v ktorých sa nenašli žiadne predmety vyrobené na území Ríma. Hoci v niektorých prípadoch možno predmety z Rímskej ríše zaradit’ medzi symboly postavenia použité pri pohrebnom rituáli, je pozoruhodné, že zohrávajú úlohu len v spojení s inými znakmi usporiadania hrobu alebo jeho inventára, nie samostatne. Vo väčšine hrobov sa predmetom $\mathrm{z}$ iných kultúrnych oblastí, $\mathrm{v}$ tomto prípade z Rímskej ríše, nepripisovala zvláštna symbolická hodnota. Na rozdiel od iných oblastí mal rímsky vplyv v prípade Sarmatov z Valašska za úlohu skôr potlačit prejavy elitného postavenia počas pohrebu.

\section{Záver}

Napriek výhradám spôsobeným chýbajúcim porovnaním so situáciou na sídliskách, pozorovania vyplývajúce $\mathrm{z}$ analýzy rímskych predmetov objavených v sarmatských hroboch z Valašska môžu prispiet nielen k ucelenému, ale priam detailnému obrazu o niektorých spoločenstvách, ktoré sa dostali do priameho susedstva s Rímskou ríšou tým, že osídlili geografický priestor d’aleko od oblastí svojho pôvodu. Hoci si tieto spoločenstvá zachovali niektoré vlastnosti typické pre populácie, ktoré písomné zdroje označujú ako "Sarmatov“ (pastiersky nomádsky spôsob života, niektoré znaky pohrebného rituálu), blízkost' k dunajskej hranici ich viditelne zmenila, v porovnaní so zvyškom Sarmatov, ktorí zostali v oblasti svojho pôvodu. 